\title{
On the Appearance of Glycogen in the Female $R e=$ productive Glands of Rodents with Special Reference to their Histology.
}

\author{
By \\ Ch. Togari. \\ From the Anatomical Laboratory, Aichi Medical College. \\ With 8 Figures (Plate XLIV-XLV). \\ Contents : \\ 1. Introduction and Literature. . . . . . . . . . . . . . 429 \\ 2. Material and Method. .............. . 434 \\ 3. Personal Observation. . . . . . . . . . . . 4455 \\ A. Rabbit. ...............4435 \\ B. Mouse. ............... . . 447 \\ C. Rat. . . . . . . . . . . . . . 456 \\ D. Guinea-pig. ............. . . . 459 \\ 4. Recapitulation and Discussion. . . . . . . . . . 462 \\ 5. Conclusion. ................. . . . . . . . . . . . . .
}

\section{Introduction and Literature.}

The female reproductive organ consists of the genital gland and the duct; and it is a well-nigh universally known fact that the physiological phenomena occurring in the latter are chiefly caused by the changes taking place in the former.

Now, detailed researches as to the appearance of glycogen in the genital duct are not small in number.

1. As to the glycogen of the Fallopian tube, Mukai (1916) noticed that it appears physiologically in the connective tissue cells of the mucous membrane of the human tube, and suggested that it may be utilized as nutrient for the embryos, considering the tubal pregnancy in connection with the fact that the appearance of glycogen is restricted to. the period of congestion only which occurs 1 or 2 days before menstruation.

Koso (1918) stated that glycogen appears in the epithelium of the 
mucous inembrane of the fimbriae and ampulla of the oviduct in the rabbit during the gestation period and the early stage of the puerperium only, never in any other normal stages irrespective of age.

I wata (1923) noted that glycogen found in the mucous epithelium and smooth muscle fibers of the human oviducts is closely related to the periodic structural changes of their mucous membrane; and is found in largest quantity during the premenstrual phase, although it is usually lacking during other phases.

2. As to the glycogen of the uterus, there are an especially large number of reports. J)riesen (1911) explained that the glycogen of the endometrium may be utilized as nutrient for embryes in their early days, considering the fact that glycogen appears in largest quantity during the premenstrual phase, increasing or decreasing hand in hand with the cyclic structural changes of the uterus, and glycogen is restricted to the corpus uteri only, never appearing in the cervix uteri in the normal condition. The similar description was published by Asch heim (1911), Ono and Kikkawa (1920) with regard to the human uterus, and they explained that the glycogen of the endometrium appears most conspicuously during the premenstrual phase, and it may be the preparation of nutrition for the ovum after its implantation.

The reports of glycogen in the gravid uterus, especially in the placenta, are rich in number. Among them, those of Goldmann (1912), Ando (1917) and Ohashi (1920) etc. entered into details, and their opinions concerning the significance of the glycogen found in the placenta are different, namely, Ando insisted that it may be necessary for the existence of the cells which contain it in the placenta, contrary to Goldmann who had declared that it may play an important rôle in the development of the embryo. Ohashi, however, recognized that it may be utilized for the nutrition of both the embryo and placenta.

3. As to the glycogen of the vagina, Niederehe (1923) remarked that the glycogen of the human vagina is distributed on its full length, being little influenced by ovary.

As described above, the detailed studies as to the glycogen of the genital duct are not small in number, but similar studies on the genital gland are scarce, and the description of the ovaries are only a minor part of their works, which were carried out chiefly with a wide scope to elucidate chiefly the significance of the appearance of glycogen.

Barfurth (1885) described in an invertebrate that "Auch die Geschlechtsdrüse mit ihren Adnexen enthält nach reichlichen Fütterung Glykogen. So finde ich nach 5 tätigen Brotfütterung bei Helix 
On the Appearance of Glycogen in the Female Reproductive Glands of Rodents. 431

promatia Glykogen in der Zwitterdrüse und zwar sehr viel in den Bindesubstanzzellen, Spuren in den Follikeln ; ferner findet sich Glykogen in den Geweben des Vas deferens, des Eileiters, der Eiweissdrüse und des Pfeilsackes. Ebenso verhalten sich Limax cinereoniger und Arion empiricorum ".

Langhans (1890) noticed in human materials that "Auch in castrierten Ovarien, die zum Theil von normaler Struktur waren, konnte ich niemals Glykogen finden; weder die Membrana granulosa, noch das Ei, noch die unreifen Follikel enthalten solches".

Fichera (1904) remarked with regard to ovaries of healthy dogs that glycogen comes out not only in many cells of the cumulus oophorus, the membrana granulosa and the corona radiata, but also in the smooth muscle fibers.

Contrary to Fichera, in the next year, Gierke (1905) reported that "In verschiedenen menschlichen Ovarien, sowie beim Kaninchen konnte ich weder in Follikeln noch im Corpus luteum Glykogen nachweisen ". Lubarsch (1906) obtained positive results with the ovaries of the dog, but enumerated the ovary as a constantly glycogen-free organ during the embryonal stage.

Kato (1909) noted that the specimens of the frog ovary are usually negative for the iodine reaction, although it contains glycogen in a large quantity, and he obtained positive results surely under the microscope by special technique.

Goldmann (1912) declared that glycogen is contained only in the ova, especially rich in quantity in their mature or divided condition, although lacking in the cells of the theca folliculi and the membrana granulosa of the growing or mature follicle in the ovaries of the mouse and rat. Hirschler (1917) noticed that glycogen appears in the female reproductive cells of the three species of Ascidia in the whole ovogenetic phases and it increases in quantity as the ovum develops.

Ando (1917) described that glycogen exists in the primitive follicle and the connective tissue of the dog and cat embryos in small quantity, although it can never be found in the reproductive glands of the rabbit embryos.

Katase and Mitsuda(1918) found glycogen in various quantities in the ovum and in a small quantity in the cclls of the membrana granulosa and the theca interna of the dog, rat and mouse, besides the positive results in the smooth muscle fibers in the wall of the ovarian arteries of the rat. 
that it contains usually no glycogen in the ovarian anlage during its larval stage, and, even in the adult, its glycogen content is different according to different seasons.

Sund berg (1924) studied the glycogen of 15, 27 and 40 mm. human embryos, and noticed that the genital cells contain glycogen, and especially the cells which may be regarded as oocytes contain sometimes granular glycogen, although they are usually glycogen-free.

Nakano (1925) reported that the ovaries of the monkey contain glycogen in the ovum and the musculature of the walls of the blood vessels.

Summarizing the above descriptions of glycogen in the ovary, it may be said that glycogen contents are likely to be larger in the lower invertebrate than in the higher vertebrate, in which glycogen is localized in certain parts of the ovary. The locality where glycogen appears, is, however, still an open question among authors, as some find it in the egg, the cells of the membrana granulosa, the smooth muscle fibers or the stroma connective tissue, while views entirely against these are held by others. The existence of glycogen in the orum is, however, about to be recognized universally.

The most detailed description of glrcogen in mammalian ovaries ever published is that of Goldmann in the mouse and rat. Even his report, however, is restricted to the ovum, denying the existence of glycogen in the other portions of ovaries, i. e., the corpus luteum, interstitial gland, follicles, stroma connective tissue, blood vessels and smooth muscle fibers at the hilum. Therefore, the relation between the appearance of glycogen in the ovary and its cyclic structural changes is totally unknown even at the present time, although the temporary appearance of glycogen in the uterine tube and uterus during the period of the passage of the orum, of pregnancy and of premenstrum is generally recognized. If there is any definite relation between them thorough observation must be accomplished as to the state of glycogen in the cells, the condition of its appearance and its biological significance, etc., which are the subjects of repeated discussion, besides stages of its appearance and the locality in the ovary.

As to the state of glycogen in the cells, it is regarded generally as semifluid substance evenly distributed in the whole cell body. Especially Fichera's experiment concerning the fixation of the liver tissue shows the clear proof of this state. According to his explanation, the glycogen of the fixed specimens of the liver cells exists in semilunar form biased toward the deeper part from the superficial part as the 
results of penetration of the fixatives. Arnold, Neukirch, Gierke and others, however, noticed that glycogen exists in combination with cell granules. Again, Barfurth, Koso and others thought that glycogen combines with a certain supporter, or the so-called 'Trägersubstanz' in the cell body. On the contrary, our Prof. 'T. Asai remarked that the glycogen in the striated muscle fibers of the mouse is comnected with the cell granules, but when rich in quantity it shows the phenomenon of 'bias' as Fichera noticed, owing to its looser connection. Ohashi, Sundberg and others stated, however, that they can not deny the theory of semifluid state of glycogen decidedly, by the irregular distribution of glycogen granules in various sizes or its masses in some tissues, although it connects clearly with cell granules at other tissues.

Regarding the condition of the physiological appearance of glycogen, there is also much divergence of opinions, and even those in opposition are insisted on as the correct ones.

1. The theory that glycogen appears when there is a diminution of cell-function, or a circulatory disturbance, as asserted by Gierke, Lubarsch, Rabe, and Schütz in pathological conditions, was amplified to the explanation of the physiological evidences. Ohashi insisted, however, that such an attempt at explanation of the physiological phenomena is one of great error.

2. The health of cells is necessary for the appearance of glycogen is the opinion hitherto held by many authors and lately emphasized by Koso. Contrary to this idea, Schütz and $\mathrm{Oki}$ noticed that it still exists in many degenerated or dead cells.

3. That glycogen appears in the tissue which is in the process of vigorous development is the theory proposed by $\mathrm{Neubert}$. This theory was, however, opposed by Gierke, Ando, Ohashi and others in views on the relations of glycogen in various tissucs of embryos.

4. The theory that glycogen appears when the metabolic activity of cells is raised is supported by Fichera, Best, Koso and others. Ohashi, however, found that all the cases of the appearance of glycogen are not to be explained with this theory alone.

5. Koso noticed that the hyperemia of the tissue is necessary for the appearance of glycogen, coincident with the healthy condition of cells, and he explained all the cases of the appearance of glycogen in physiological and pathological states on the basis of these two conditions. On the contrary, Ohashi and $\mathrm{Oki}$ noticed that such an explanation with one and the same condition for all the cases of glycogen appearance in various states is not correct. 
6. The theory that good nutrition, excessive supply and insufficient consumption cause the appearance of glycogen is supported by Barfurth, Gierke, Fichera, Lubarsch, Ando and others, and is recognized by almost all the authors to these day's.

Furthermore; the problem as to the biological significance of the glycogen appearance is at present still an open question and a large number of theories have been proposed as follows:- (Gierke, Krestadt, Koso, Ohashi, Sundberg).

1. Glycogen is not only nutrient for the cells which contain it but it also participates in their constitution (Bernard).

2. Glycogen is utilized for the execution of the function of the cells which contain it.

3. Glycogen exists merely as a nutritive supply not necessary for the cells which contain it, but for other cells.

4. Glycogen appears in the tissue which is wanting in blood ressels, as the representation of hemoglobin (Creighton).

5. Glycogen appears as a by-product at the time of the decomposition of albumen or other complicated substances (Barfurth).

6. Glycogen is an obligatory, and not an optional step in the formation of blood sugar from the non-carbohydrate stores of the organism (Markowitz).

\section{Material and Method.}

For the solution of numerous problems described in the introduction, we must rely upon the complete study of the glycogen distribution and the structual changes in the various tissues of a large number of accurately timed ovaries. Hence, the majority of the animals utilized in this research are accurately dated. They are 125 in number as described in the tables under the personal observation, namely, 41 rabbits, 73 mice, 3 rats, and 8 guinea-pigs.

These animals were killed by striking, decapitation or narcosis with chloroform or ether. The ovaries of the one side were taken from the abdominal carity immediately, placed in Carnoy's mixture, embedded in celloidin or celloidin-paraffin, made into sections of 10-15 $\mu$. in thickness and stained with Best's carmine solution (Asai's modified solution). Besides, some of them were stained by Langhans' nethod with Lugol's solution, and the salivary reaction was often applied. The ovaries of the other side were put into Zenker's, Orth's or Flemming's solution, cmbedded in celloidin, paraffin or celloidin-paraffin, made int s 
On the Appearance of Glycugen in the Female Reproductive Glands of Rodents. 435

sections of 5-10 $\mu$. in thickness and stained with Hansen's hematoxylin eosin, Heidenhain's iron-hematoxylin, Weigert's elastic fiber stain and modified Traina's connective tissue stain. The former set of preparations were used for the study of glycogen distribution and the latter set for the minute structure of the ovaries.

Moreover, 3 rabbits vitally stained with lithium carmine were utilized for the study of histiocytes in the atretic follicles. These ovaries were fixed in 10 per cent formalin solution, embedded in paraffin, made into sections of 5-10 $\mu$. in thickness and stained simply with Hansen's hematoxylin. For the study of fats, 8 ovaries obtained from rabbits and mice were fixed in 10 per cent formalin solution, made freezing sections and stained with sudan III.

Following two cautions are especially necessary in carrying out Best's staining.

1. The minute glycogen granules are totally masked when the preparations are stained deeply with hematoxylin. Hence, it is preferable that the nucleus should be stained slightly with diluted hematoxylin solution just enough to know its existence or without any nucleal staining in case the amount of glycogen is very small.

2. The ammonia solution necessary in preparing Best's solution is extremely diluted with water under Prof. T. A sai's direction. With this solution, glycogen granules show bright crimson, unless they are stained usually dark red. When the ammonia solution evaporates readily as it does in summer, a few drops of fresh solution are at times to be supplemented into Best's solution and shaken thoroughly before the staining.

In the following, I will describe the substance, which shows granules oi' masses stained red with Best's solution and which is positive to the salivary reaction, as the true glycogen, and other types of glycogen showing similar reactions, as the glycogen like substance.

\section{Personal Observation.}

\section{A. Rabbit.}

1. Ovaries of embryo and sucklings.

Ovaries observed during these periods are those of embryo 26 days after copulation and of sucklings 1 and 9 days after birth. These oraries are similar in structure, showing the embryonal appearance without any primitive follicles, although they grow twice in size during these periods.

a. 26 day embryo.

The ovary consists of the germinal epithelium, cortical and medullary 
portions. The germinal epithelium of stratified epithelial cells shows often mitotic divisions and contains here and there primitive ova with large spherical nuclei and rich in cytoplasm. The cortical portion consists of Pflüger's egg tubes and the small amount of connective tissue among them. The former rich in primitive ova and mitotic divisions is connected directly with the germinal epithelium, and the latter runs from the medullary portion to the germinal epithelium, and its fibers run like fibrous fetts, not parallel nor reticulum. The indifferent epithelial cells in cords or clusters of the medullary portion are smaller than those of the cortical portion, and are relatively rich in. amount. There are no interstitial gland cells in the ovarian stroma. Glycugen is contained in any portion of the ovaries, with the exception of the indifferent epithelial cells of the medullary portion which contain a little glycogen-like substance. The epithelial cells of the uterine tube are, however, loaded with granular glycogen.

b. 1 day sucklings.

Ovaries at this period show similar structure to those of the former period. The connective tissue in the medulla has, however, increased a little in amount, accordingly the epithelial cells of the profound part of the ovary become far smaller in the terms of cords or of clusters. No interstitial gland cells are present in the stroma connective tissue. Glycogen is found in some ovaries, whereas others lack it. Glycogen appears in the epithelial cells both of the cortex and the medulla as minute granules biasing towards the profound part. Therefore they present on the whole a semi-lunar form in the cytoplasm. Besides, the walls of the small blood vessels in the ovarian stroma contain small granules surrounding their small cavities concentrically. In the Fallopian tube, glycogen granules appear not only in its epithelium, but also in its lumen.

c. 9 day suckling.

The connective tissue of the cortex is increased in amount, and also that of the medulla. The epithelial cords or clusters begin, therefore, to be subdivided into epithelial islets, not only in the smaller epithelium of the medulla, but also in the larger one of the cortex. These epithelial cells contain many primitive ova. The ovary at this period consists of three zones; the germinal epithelium, the large and the small cellular layer. Among the stroma connective tissue cells, no interstitial gland cells are met with.

Glycogen distribution is particularly noteworthy. Minute granules exist in the germinal epitholium, biasing toward its basal portion. The 
On the Appearance of Glycogen in the Female Reproductive Glands of Rodents. 437

same condition is found in the large cellular layer, their granules being biased toward the small cellular layer, although in this layer they are distributed universally in the cytoplasm of the small indifferent epithelial cells. The stroma blood vessels contain glycogen in their walls, while the surrounding stroma connective tissue contains none. There is also much glycogen in the epithelium and the inner cavity of the Fallopian tube at this period.

\section{Ovaries of adults.}

Germinal epithelium.

The epithelial cells which cover the surface of the ovary are columnar, cubical or squamous in shape, and contain usually no glycogen, except in a case at the first day after copulation, in which smaller amount of glycogen is noticed in their basal parts.

Tunica albuginea and stroma connective tissue.

The tunica albuginea is sufficiently developed, composing several layers of connective tissue cells with elongated fusiform nuclei, and is more fibrous than the other connective tissue of the ovarian stroma. The connective tissue of the cortex is relatively little surrounding the several interstitial gland cells, or combining the medulla and the tunica albuginea, although that of the medulla is somewhat rich in amount, surrounding a large number of blood vessels. The stroma of the cortex shows, in some cases, the condition similar to that of the guinea-pig, in which it consists of numerous networks of several layers of the connective tissue cells. The ovarian stroma contains no elastic fibers, except in the walls of the blood vessels. Glycogen is not found anywhere at any stage.

Smooth muscle fibers.

Smooth muscle fibers of the ovary are found in two portions; namely, those consisting of the fibromuscular tissue of the hilum and those of the walls of the blood vessels, which occupied the larger portion of the medulla. The former is restricted, in general, to the hilum, although some of muscle fibers penetrate rarely deep into the medulla, not, however, reaching the theca externa of the follicles. Glycogen of these muscle fibers is often found in abundance during the early periods of pregnancy, although it is usually small in amount, and is rarely found during normal stages. In the cytoplasm of the smooth muscle it appears as small grains or droplets at both poles of the rod-shaped nuclei, or as a line of granules arranged along the long axis of cells, and biased toward one side. The latter is composed of the muscular wall of the arteries and veins which are characterized by their spirally tortuous 
courses. Stage and state of glycogen appearance in the latter just. correspond to those in the former.

Follicle.

Oraries of the adult rabbit contain many follicles in various stages of development from the primordial to the mature stage. When the follicle grows to hold about 2 layers of granulosa cells, the sheath of the follicle may be distinguished in two portions; the theca interna and the theca externa. Hence, the formation of the theca interna is a little earlier than in the other mammals I have studied.

1. The theca externa. The theca externa of the mature follicle consists of 4 or 5 layers of connective tissue cells, developed from a single layer of the primordial follicle. Among these cells there are delicate connective tissue fibers, but no elastic fibers, nor smooth muscle fibers. This layer is arranged concentrically and densely, showing the clear cut limits against outer interstitial gland cells and inner theca interna cells. These cells show elongated spindle shape with deeply stained nuclei. Glycogen is negative in every stage except in two preparations obtained 7 days after parturition and 1 day after copulation, in which minute granules are found at both poles of their nuclei.

2. The theca interna. This layer of the mature follicle is composed of 1-3 layers of polygonal cells, usually arranged concentrically. They are large and polygonal, their cytoplasm show honey-combed appearance and their nuclei are spherical or elliptical, containing a few chromatin. These cells sometimes show mitotic divisions. Besides the polygonal cells of the theca interna, there exist also spindle-shaped cells which are homologous to the theca externa cells. The capillaries in this layer form a delicate network which lies especially near the basement membrane. Glycogen in the cytoplasm of the polygonal cells is noticed in granular forms 7 days after parturition, and 1 and 5 days after copulation.

3. The basement membrane. The basement membrane exists inside of the theca interna, surrounding closely the granulosa layer concentrically and it shows a clear, unstained, homogeneous line with Bestis staining.

4. The membrana granulosa. This layer is composed of a layer of squamous cells which surround a single ovum in the primitive follicle. With the development of the follicle, these cells increase their heights. and show a high columnar shape, and multiply by mitotic divisions. As the follicle grows, the height of these cells diminishes again to become short and columnar, elliptic or spherical about the time when the accumulation of the liquor folliculi begins. In the mature follicle it 
On the Appearance of Glycogen in the Female Reproductive Glands of Rodents. 459

is several cells thick and is arranged radially around the whole circle. The outer border of this layer is arranged regulary resting upon the basement membrane, which is quite different from those of the atretic follicles or follicles directly after rupture. Contrary to the outer border, the inner facing the antrum folliculi is arranged irregularly. The discus proligerus can never be seen in the mature follicle, and the corona radiata surrounding the ovum spreads out a few strands of cells radially to the granulosa layer. This is due to the fact that the liquor folliculi begins to accumulate almost synchronously at many places, especially near the ovum in the growing follicle; consequently, certain of the granulosa cells are torn apart so as to form many fluid-filled spaces showing the sponge-like appearance of the granulosa layer, and as these spaces are enlarged, it finally obliterates the discus proligerus formation. The granulosa cells of the mature follicle are small, round or oval, their cytoplasm is little and looks granular, and their nuclei without nucleoli are stained deeply with hematoxylin. Many cell divisions are seen everywhere, but the degeneration appears occasionally in a $\mathrm{f} \cdot \mathrm{w}$ cells facing the antrum folliculi. No glycogen is usually observed in the epithelial cells.

5. The liquor folliculi. The liquor folliculi appears soon after the differentiation of the theca interna and the externa is established, and it. accumulates further in the mature follicle. So-called Call-Exner bodies which may serve in the liquor formation, are found in a large number, not only in the growing follicles, but also in the mature ones. They are spherical cavities of various sizes surrounded by the granulosa layer, as the corona radiata. They show a reticular structure which usually stained granular or diffuse with Best's solution. Liquor folliculi also is often stained diffuse or granular with carmine solution.

6. The egg. The egg shows a round vesicle, and consists of the ovum and the zona pellucida. The former contains glycogen and glycogen-like substance rarely but in a minute quantity in its cytoplasm. The latter, however, shows usually no glycogen reaction.

Corpus luteum.

There are no recognizable histological differences, other than those of size and duration, between the corpus luteum verum and the corpus luteum sprium. The majority of the lutein cells in the rabbit are derived from the granulosa cells of the mature follicle after rupture, not only by their hypertrophy but also by their hyperplasy, and a part of the lutein cells are the remainder of the theca interna cells. The blood vessels of the corpus luteum are derived from those of the theca interna. 
and the connective tissue reticulum among the lutein cclls and the central connective tissue nucleus of the corpus luteum are formed from the spindle-shaped cells of the theca interna and the externa by their multiplication by cell division. The corpus luteum thus formed in the rabbit degenerates after fulfilling its function; namely, the majority of the granulosa lutein cells disappear through fatty degeneration, and a nart of them after they are converted into the pigment cells.

The theca lutein cells also degenerate and disappear, never reverting to the connective tissue cells. The connective tissue reticulum and the central nucleus of the corpus luteum are gradually absorbed and disappear following the degeneration of the lutein cells, but they remain long in part to form a kind of corpus fibrosum. Even this body disappears finally, not forming the corpus albicans by its further contraction and hyaline degeneration. Blood vessels are also obliterated and absorbed gradually together with the connective tissue above described.

The glycogen appearance in the corpus luteum is particularly noteworthy.

1. Glycogen of the corpus luteum sprium in its fully grown stage is found in a small amount in two cases, but not in one case.

2. Glycogen of the corpus luteum verum begins to be found in the lutein cells at 3 dars after copulation when these cells enlarge after multiplication by cell division. Glycogen increases gradually in amount, and reaches its maximal quantity at 6 days after copulation (Fig. 1). And then it decreases gradually towards 12 or 13 days after copulation. After this up to the late stage of gestation, it can never be seen. However, it reappears in the degenerating corpora lutea after parturition, especially in large quantity in the groups of degenerating lutein cells with pycnotic nuclei. Pigment cells converted from the lutein cells do not show any reaction of glycogen.

Glycogen found in the corpus luteum is largest in quantity in the rabbit among the whole of the rodents which I have studied. Glycogen contents are almost equal in quantity between the corpus luteum and the corpus haemorrhagicum which were synchronously formed; and the same is true between the central and peripheral parts and between the superficial and profound parts of a corpus luteum. The glycogen contents of each lutein cell, however, greatly differs even in the same corpus luteum. When glycogen appears in small amount, it takes the form of minute globlets existing perhaps coincident with the cell granules or with the walls of the honey-combed structure of the lutein cells, while 
On the Appearance of Glycogen in the Female Reproductive Glands of Rodents. 441

the large amount of glycogen appears as masses or droplets and biased toward the profound part (Fig. 1).

Glycogen reaction is negative in the connective tissue reticulum among the lutein cells throughout their whole life, except the large round and universally distributed granules of the mast cells which wandered into the reticulum of the degenerating corpus luteum. The central nucleus of the corpus luteum shows usually negative reaction with Best's staining, but in one case fine granular glycogen appeared in the young connective tissue cells during the formation of the corpus luteum.

The state of the glycogen distribution in the blood vessels of the corpus luteum is peculiar, appearing not only in their walls, but also in their inner cavity. It begins to appear at 4 days after copulation, reaches its maximum amount at 5 or 6 days after copulation and then decreases gradually, existing in a small amount during the stages in which it may be found in the lutein cells. Glycogen of the blood vessels is usually in the form of minute granules appearing after along the course of the capillaries in their endothelial cells and in the peripheral part of their inner cavities.

An exceptional case is found in a corpus luteum during its formation period, in which the egg remains at the center of the central cavity of the corpus haemorrhagicum at 2 days after copulation. Its ovum and the cells of the corona radiata surrounding it are in degeneration contrary to the increase by cell divisions of the granulosa layer touching the basement membrane. This corpus luteum was positive for glycogen in the orum, the granulosa cells of the corona radiata, the leucocytes of the central cavity, but was negative in the majority of the growing granulosa cells and in the cells of the sheath.

Atretic follicle.

Many follicles fall into atrophy beneath the tunica albuginea. Especially, most follicles larger than the medium-sized in the gestation period fall into atrophy as there is usually no ovulation. The changes occurring in every layer of follicles in atrophy and their glycogen reactions are as follows:

1. The theca externa. Smaller follicles have thinner sheaths without any distinction of the theca externa and the theca interna. Through the atrophy of these small follicles, the sheaths are left usually in situ after the degeneration of the ova and the granulosa cellis, and form the walls of small round cavities formed by their disappearance. In other words, the phenomenon of the so-called 'small cystic atroply' is found 
in the rabbit ovary also. The wall of the small cyst is composed of, therefore, 1 or 2 layers of connective tissue cells in concentric arrangement, and the cyst often contains the zona pellucida. These small atretic follicles show negative reaction for Best's stain.

In the atrophy of the follicles larger than the medium-sized, the polygonal cells of the theca interna are enlarged and increase in number by converting the spindle-shaped cells into the polygonal together with the degenerative process of the ova and the granulosa cells. The spindle-shaped cells among the polygonal increase also in number, and penetrate into the degenerated granulosa layer through the basement membrane, although the majority remains to form the interstitial tissue of the enlarged polygonal cells. The theca externa cells also invade inner side following the above-described spindle-shaped cells of the theca interna. In a further advanced condition, the theca externa loses its continuity, by the growth of the polygonal cells, which are, therefore, in direct contact with the adjacent fully grown interstitial gland. The glycogen in the theca externa of the atretic follicles larger than the medium-sized is usually negative during the gestation period, but found rarely and finely in the other stages.

2. The theca interna. The polygonal cells which form the main part of the theca interna. are increased in number through the enlargement of spindle-shaped cells, and are converted into the typical interstitial gland cells without any cell division. The spindle-shaped cells of this layer invade the degenerating granulosa layer with cell division being also arranging radially. After the disappearance of the granulosa cells, spindle-shaped cells show a confused arrangement, running in various directions, or a concentric arrangement surrounding a small cavity or the remaining zona pellucida in the center of the atretic follicles, as in the case of the central connective tissue nucleus of the corpus luteum. The connective tissue among the enlarged polygonal cells, i. e., young iuterstitial gland cells, surrounds several of them so as to form a lobe. The capillaries run along with the connective tissue reticulum above described and come finally in contact with one side of almost every interstitial gland cell. The polygonal cells often show minute glycogen in their cytoplasm in the normal stages, but abundantly in the early stages of pregnancy. The connective tissue reticulum, the central connective tissue nucleus and the capillaries usually contain no glycogen.

3. The basement membrane. In the atrophy of the small follicles, the membrane remains between the membrana granulosa and the theca 
On the Appearance of Glycogen in the Female Reproductive Glands of Rodents. 443

folliculi, composing delicate connective tissue fibers, and finally forming the innermost wall of the small cyst. On the contrary, in the atretic follicles larger than the medium-sized, it gradually increases in thickness with the progress of their atrophy, and suffers, further, hyaline degeneration. At several points of this thick, hyaline layer, it often contains connective tissue cells which are on the point of penetrating from outside into inside. Hyaline degenerated basement membrane is homogeneous, stained reddish with Best's solution as seen in the hematoxylin-eosin staining.

4. The membrana granulosa. In the small follicles, this layer degenerates and disappear's almost synchronously with the ovum, but in the follicles larger than the medium-sized it degenerates earlier, or later than the ovum, and seldom synchronously. The first phenomena of the atretic follicles are the appearance of histiocytes in the ovum and in this layer, and the disappearance of the cell division seen abundantly in the normal follicles. The degenerative process begins usually at the part facing the antrum folliculi. During the degeneration of the granulosa cells, their arrangement becomes irregular, especially early in the outermost cells adherent to the basement membrane. The granulosa cells become deteriorated and totally liquefy after their various degenerative changes as described below:-Some of their nuclei become gradually unstainable and dissolved in the liquor folliculi, or their chromatin becomes globular in various sizes which wander into the liquor folliculi, their cytoplasm being also liquefied. These globulets are usually deeply stained with hematoxylin, although some of them are stained faintly, and some become large globulets larger than the granulosa cells apparently by fusing together. Their cytoplasm in degeneration contains usually substance stained with sudan III, which usually disappear in the normal condition, or else they are swollen or become withered. Contrary to the above-described degenerative process, the granulosa cells may exist for a long time and may be converted into lutein cells in some exceptional cases. Glycogen of the granulosa cells in degeneration are seen as large granules in their swollen cytoplasm, or as fine granules, being universally distributed in the cells of the corona radiata, which are apparently normal, but show no cell division. Histiocytes of various sizes contain usually no glycogen.

5. The liquor folliculi. The liquor folliculi is absorbed gradually and disappears, showing no increase. Hence the phenomenon of the cystic degeneration of the follicle is absent in the rabbit ovary although some atretic follicles show sometimes a large hemorrhage into their cavities. The liquor folliculi of the atretic follicles is stained usually 
deeper than that of the normal follicles. The reticular structures of the so-called Call-Exner bodies are usually granular and stained red with Best's solution. The liquor folliculi is also often in granular form.

6. The egg. In the atrophy of the small follicles, the ovum degenerates and disappears with the zona pellucida leaving no trace, or it disappears leaving the degenerated zona pellucida behind. In the larger follicles, it leaves usually the twisted zona pellucida after the disappearance of the ovum. In the early stages of the atretic follicles, some histiocytes penetrate often into the space between the ovum and the zona pellucida, or into the cytoplasm of the ovum. The ova often show polar bodies or the appearance of dividing into two or more cells within the zona pellucida. In further advanced follicular atrophy, they turn into, however, granular masses deeply stained with eosin and containing no nuclei. The glycogen in the degenerating ovum is larger in amount than that of the normal ovum. The zona pellucida in a twisted band is stained homogeneously reddish with Best's solution the same as the basement membrane. The histiocytes found within the zona pellucida contain usually no glycogen.

Interstitial gland.

The interstitial gland is most highly developed in the rabbit among the animals I have studied. Interstitial gland cells are derived from the polygonal cells of the theca interna by the atretic follicles as formerly noticed. Three stages can be distinguished among these cells, although intermediate stages are of course noticed, namely: 1. Young interstitial gland cells, 2. Fully grown interstitial gland cells and 3. Degenerating interstitial gland cells.

Young interstitial gland cells are similar to the polygonal cells of the theca interna of the Graafian follicle, containing spherical nuclei rich in chromatin and granular or fine honey-combed cytoplasm stained faintly with eosin. Grown interstitial gland cells contain large spherical nuclei, with poor chromatin, placed excentrically in their cytoplasm which shows the appearance of large honey-comb stained deeply with eosin. 'They possess usually no capsule derived from the theca externa of the atretic follicles, although the young interstitial gland is often covered with a thin capsule. They are a little smaller than the fully grown lutein cells in size, and are arranged irregularly, several of them being surrounded in groups by the stroma connective tissue and capillaries. Among these cells, degenerating interstitial gland cells are found in groups or separately. Degenerating interstitial gland cells are 
On the Appearance of Glycogen in the Female Reproductive Glands of Rodents. 445

usually smaller than the former, containing pycnotic or caryolytic nuclei. Their cytoplasm is very different; varying from the minute honey-combed stained faintly with eosin, large honey-combed scarcely stained with eosin, to the type containing much yellowish pigment.

Glycogen of the interstitial gland cells appears rich in quantity being seconid to the lutein cells. It appears often even in the non-pregnant

Table I.

Glycogen of ovaries in pregnant rabbits.

\begin{tabular}{|c|c|c|c|c|c|c|c|c|c|c|c|c|c|c|c|c|c|c|}
\hline \multicolumn{2}{|c|}{ Rabbit number } & & & & & & & & & & 0 & & 12 & 13 & 4 & 15 & 16 & \\
\hline \multicolumn{2}{|c|}{ Time after copulation } & & d & & & & & & & & & & $\begin{array}{l}0 \\
1\end{array}$ & & 2 & is. & 8 & \\
\hline \multirow{2}{*}{\multicolumn{2}{|c|}{$\begin{array}{l}\text { Germinal epithelium } \\
\text { Tunica albuginea and } \\
\text { Stroma connective tissue }\end{array}$}} & & & & & & & & & - & t & -1 & - & - & - & - & - & \\
\hline & & & & & & & & - & - & - & - & - & - & - & - & - & $\rightarrow$ & \\
\hline \multicolumn{2}{|c|}{ Muscle of hilum } & & & & & & & - & & - & -1 & -1 & - & - & - & - & $-i$ & \\
\hline \multicolumn{2}{|c|}{ Muscle of blood ressels } & 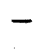 & 7 & & & & & T & + & - & - & -1 & - & \pm & - & - & - & \\
\hline & Theo oxtorne & - & + & - & & 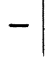 & 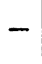 & - & - & - & - & - & - & - & - & - & - & \\
\hline & interna & & + & - & - & & + & -1 & - & - & - & - & - & - & - & - & - & - \\
\hline & $\mathrm{Ba}$ & r & - & - & - & - & - & - & -1 & $\cdots$ & - & - & - & - & - & - & - & - \\
\hline & & & - & - & 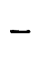 & 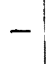 & - & - & - & - & - & - & - & - & - & - & - & - \\
\hline & & & \pm & - & \pm & - & - & - & - & - & - & - & - & - & - & - & -1 & -3 \\
\hline \multirow{3}{*}{ 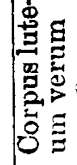 } & tain colla & - & - & \pm & - & + & & - & & & & & $\cdot$ & & • & - & & \\
\hline & Grown " & & 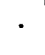 & 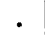 & & & & $\stackrel{+}{+}$ & ++ & + & + & \pm & + & \pm & \pm & \pm & - & \\
\hline & egenerating ", & \pm & \pm & + & - & \pm & \pm & + & \pm & $\cdot$ & • & • & $\because$ & $\cdot$ & • & - & & \\
\hline & & & - & - & - & - & - & - & - & - & - & - & - & - & - & - & - & - \\
\hline \multirow{5}{*}{ 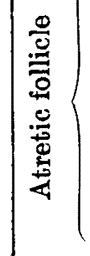 } & (3) & & \pm & + & $I$ & - & + & + & + & - & - & - & - & - & - & - & - & - \\
\hline & $\begin{array}{l}\text { Basement mem- } \\
\text { brane }\end{array}$ & - & - & - & - & - & - & - & - & - & - & - & - & - & - & - & - & -3 \\
\hline & a granu- & - & T & + & + & + & + & + & + & - & - & - & - & - & - & - & - & - \\
\hline & & & + & ++ & + & + & + & + & + & + & - & 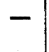 & + & + & + & + & -1 & \pm \\
\hline & & - & - & - & - & - & - & - & - & - & - & - & - & -1 & - & - & -1 & - \\
\hline \multirow{3}{*}{ 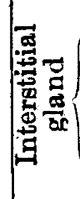 } & $\begin{array}{l}\text { nterstitial } \\
\text { cells }\end{array}$ & - & \pm & + & 1 & + & + & i & + & - & - & - & - & 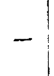 & - & - & - & - \\
\hline & Gr & - & + & + & + & + & + & ++ & + & \pm & - & - & -1 & \pm & - & \pm & - & -3 \\
\hline & $\begin{array}{l}\text { ating } \\
" \quad "\end{array}$ & _ & + & + & + & + & + & + & + & \pm & -1 & - & - & - & - & - & -1 & - \\
\hline
\end{tabular}




\section{Table II.}

Glycogen of ovaries in non-pregnant rabbits.

\begin{tabular}{|c|c|c|c|c|c|c|c|c|c|c|c|c|c|c|c|c|c|c|c|c|c|}
\hline \multicolumn{2}{|c|}{ Rabbit number } & 1 & 2 & 3 & 4 & 5 & 6 & 7 & 8 & $9 \mid 1$ & 10 & 12 & $2 \mid 13$ & $|3| 1$ & $14 \mid 1$ & 151 & $1 6 \longdiv { 1 }$ & 17 & 18 & 19 & 20 \\
\hline \multicolumn{2}{|c|}{ Time after parturition } & $\begin{array}{l}7 \\
d\end{array}$ & $\begin{array}{c}20 \\
\mathrm{~d}\end{array}$ & $\begin{array}{c}22 \\
d\end{array}$ & $\begin{array}{c}24 \\
\mathrm{c}\end{array}$ & $\begin{array}{c}26 \\
\mathrm{~d}\end{array}$ & $\begin{array}{c}29 \\
d\end{array}$ & $\begin{array}{c}30 \\
\mathbf{d}\end{array}$ & $\left|\begin{array}{c}31 \\
d\end{array}\right|$ & $\begin{array}{l:l}33 & 4 \\
4 & 4 \\
4\end{array}$ & & & & & & $\begin{array}{l}63 \\
d\end{array}$ & $\begin{array}{c}0.3 \\
d\end{array}$ & $\cdot$ & $\theta^{\circ}$ & & . \\
\hline \multirow{2}{*}{\multicolumn{2}{|c|}{$\begin{array}{l}\text { Germinal epithelium } \\
\text { Tunica albuginea and } \\
\text { troma connective tissue }\end{array}$}} & - & - & - & - & - & - & -1 & $-1-$ & $-1-$ & $-1-$ & -7 & -- & - & - & $-1-$ & $-1-$ & - & -1 & -1 & 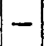 \\
\hline & & -1 & - & - & - & - & - & - & $-1-$ & - & & 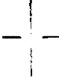 & & 一 & -1 & -1 & -- & - & - & - & - \\
\hline \multicolumn{2}{|c|}{ Muscle of hilum } & + & - & - & - & + & + & \pm & - & - - & - & - & & - & - & - & - & - & -1 & -1 & - \\
\hline \multicolumn{2}{|c|}{ Múscle of blood vessels } & - & - & - & - & - & - & - & - & - & - & - & & - & - & - & - & - & - & - & - \\
\hline \multirow{4}{*}{$\stackrel{\frac{0}{0}}{ٍ}$} & Theca externa & \pm & - & - & - & - & - & - & -1 & - & - & - & & 一 & - & -7 & - & - & - & - & - \\
\hline & $"$ interna & \pm & - & - & - & - & - & - & -1 & - & - & - & - & - & - & - & - & - & - & - & - \\
\hline & Basement membrane & - & - & - & - & - & - & - & - & - & - & - & - & - & - & - & - & - & - & - & - \\
\hline & $\begin{array}{l}\text { Membrana gra- } \\
\text { nulosa }\end{array}$ & - & - & - & - & - & - & - & - & - & 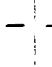 & - & & - & - & - & - & - & - & - & - \\
\hline \multirow{4}{*}{ 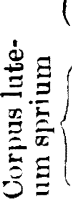 } & 0 & + & - & - & - & - & - & - & - & - & - & $-1-$ & & - & - & 一 & - & - & - & - & - \\
\hline & cells & - & $\cdot$ & $\cdot$ & - & - & - & . & $\cdot$ & • & - & • & $\cdot$ & • & • & • & • & • & - & $\cdot$ & • \\
\hline & Grown $" \quad "$ & $\cdot$ & $\cdot$ & • & • & • & • & $\cdot$ & - & - & - & - & - & - & • & - & • & + & + & - & - \\
\hline & Degenerating ," " & $\cdot$ & $\cdot$ & $\cdot$ & $\cdot$ & $\cdot$ & $\cdot$ & $\cdot$ & - & & - & - & • & - & - & - & • & • & - & - & . \\
\hline \multirow{3}{*}{ 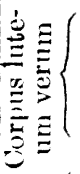 } & Young , " & . & - & · & • & $\cdot$ & $\cdot$ & • & $\cdot$ & . & • & - & - & • & - & - & - & • & $\cdot$ & $\cdot$ & $\cdot$ \\
\hline & Grown $\quad " \quad "$ & 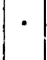 & - & - & - & • & · & · & • & & 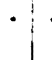 & - & - & - & - & - & $\cdot$ & - & - & - & $\cdot$ \\
\hline & Degenerating " " & + & - & $\cdot$ & . & + & . & - & $\cdot$ & - & - & . & - & - & . & - & • & - & - & • & - \\
\hline \multirow{5}{*}{ 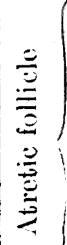 } & eca externa & + & - & - & - & - & - & \pm & - & - & - & +- & & - & - & - & - & - & - & - & - \\
\hline & $"$ interna & 17 & - & - & - & - & - & \pm & - & $-=$ & \pm & + & -+ & + & - & -1 & - & - & - & - & - \\
\hline & Basement membrane & - & - & - & - & - & - & - & - & - & - & - & - & - & - & - & - & - & - & - & - \\
\hline & $\begin{array}{l}\text { Membrana gra- } \\
\text { nulosa }\end{array}$ & + & + & - & + & -1 & + & + & + & + & $+=$ & \pm+ & +1 & \pm & - & + & + & 一 & - & - & + \\
\hline & Ovum & 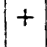 & + & + & - & - & + & + & \pm & + & + & -1 & & - & - & - & + & + & + & + & - \\
\hline \multirow{4}{*}{ 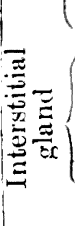 } & Histiocytes & 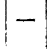 & - & - & - & -1 & - & - & - & - & - & - & & - & - & - & - & - & - & & - \\
\hline & $\begin{array}{l}\text { Young interstitial } \\
\text { gland cells }\end{array}$ & \pm & - & - & - & - & - & \pm & - & - & + & + & & \pm & - & - & - & - & - & + & + \\
\hline & Grown " " " & 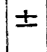 & - & - & - & - & - & \pm & & & + & + & - \pm & \pm & - & - & - & - & - & -1 & + \\
\hline & $\begin{array}{c}\text { Degenerating } \\
", ",\end{array}$ & $T$ & - & - & -1 & - & - & \pm & - & -1 & + & + & - \pm & \pm & - & $-1-$ & $-1-$ & - & - & \pm & + \\
\hline
\end{tabular}

period, but more vigorously in the pregnant, especially at almost the same stages as the corpus luteum graviditatis. Glycogen in the young interstitial gland cells is finely granular, that in the fully grown inter- 
On the Appearance of Glycogen in the Female Reproductive Glands of Rodents. 447

stitial gland cells is in granules or droplets, much of it biased toward the medulla (Fig. 2), and in fine granules little in quantity seen along the walls of honey-combed structure, and that in the degenerating interstitial gland cells shows the same appearance as that of the fully grown case of the latter. The glycogen granules of walls and cavities of the capillary among the interstitial gland cells are more remakable than those of the corpus luteum, and their amounts are usually larger than those of the adjacent interstitial gland cells.

\section{B. Mouse.}

1. Ovaries of sucklings.

a. 6 day suckling.

The ovaries of a suckling mouse are well developed in structure compared with those of the rabbit of about the same stage. Their germinal epithelium contains many ova, and Pflüger's egg tubes have disappeared already. The cortical portion is chiefly composed of many primordial follicles while the medullary portion contains, in addition a little larger follicles with 2 layers of granulosa cells. There is a little connective tissue among these follicles, without, however, any typical interstitial gland cells. Glycogen is negative in every part, except a trace of it found in the ova of the follicles with 2 layers of granulosa cells.

b. 10 and 12 day sucklings.

The germinal epithelium often contains ova. The cortical portion is composed chiefly of primordial follicles and the medullary portion is made up of a little larger follicles with 2 or 3 layers of granulosa cells. There are no typical interstitial gland cells. Glycogen is contained only in the ova and in the walls of the blood vessels in minute amount.

\section{Ovaries of adults.}

Germinal epithelium.

The germinal epithelium composed of squamous to columnar epithelial cells contains no glycogen either during the pregnant or in other periods.

Stroma connective tissue.

The stroma connective tissue is poor in amount, lacking the typical tunica albouginea formation. Contrary to the condition in the rabbit ovary only a little connective tissue can be noticed around the blood vessels of the medulla and among the follicles, the corpora lutea and the interstitial glands. Connective tissue cells show spindle shape, and usually contain no glycogen. 
Smooth muscle fibers.

The portions where smooth muscle fibers exist, are the walls of the blood ressels and at the hilum. In the central part of the ovary of the adult mouse, we can usually notice the existence of the central cavity as described in my former work entitled "On the retrogression of the corpus luteum of the mouse". Hence, the blood vessels in the medulla often show trabecular appearance of the central cavity. Glycogen is not found in the smooth muscle fibers at the hilum during the pregnant, nor in the nou-pregnant period, except in one case at 2 days after parturition. In the walls of the blood vessels, especially of the small arteries, glycogen is often noticed. The state of glycogen in the smooth muscle fibers of the mouse is similar to that of the rabbit, except its smaller quantity in the former.

Follicle.

There are many follicles in various stages of their development from the primordial to the mature follicles. In the growing follicles, the theca interna begins to differentiate from the sheath, when the liquor folliculi is about to accumulate among the granulosa epithelium, a little later than in the case of the rabbit.

1. The theca externa. This is composed of only 2 or 3 layers of connective tissue cells arranged concentrically in the mature follicles. These cells are of spindle shape, rich in nuclear chromatin and poor in cytoplasm, which contain usually no glycogen.

2. The theca interna. In the mature follicles, this consists of 1-3 layers of polygonal cells and the spindle-shaped cells as that of the rabbit. The capillary network among them lies especially near the basement membrane. The nuclei of the polygonal cells are spherical or elliptical, containing a few chromatin, without any cell division, and their cytoplasm is honey-combed or granular in appearance, often containing glycogen during the non-pregnant period, but not during the pregnant period.

3. The basement membrane. This exists between the membrana granulosa and the theca interna, consisting of delicate connective tissue fiber's, and is never stained with Best's solution.

4. The membrana granulosa. In the mature follicles this area is thicker than in the rabbit, although it is developed from a layer of squamous cells of the primitive follicles in the same manner as in the latter animal. A cone-shaped or rounded projection of it or the cumulus oophorus is formed, and it holds the ovum near its apex. The granulosa cells are small, round or oval, with small round nuclei rich in chromatin 
On the Appearance of Glycoren in the Female Reproductive Glands of Rodents. $\mathbf{4} 49$

and a little cytoplasm. They show many mitotic divisions, but a few of the cells facing the antrum folliculi occasionally undergo degeneration. They are usually negative for the carmine staining.

5. The liquor folliculi. The fluid begins to accumulate when the differentiation of the theca interna and the externa appcars, and the mature follicles contain it abundantly, although in smaller amount than in the case of the rabbit. So-called Call-Exner bodies are scarcely met with. With Best's solution, it is scarcely stained or gives an appearance of reddish strings arranged radially around the ovum, but is rarely stained as red granules.

6. The egg. The ovum is a round vesicle surrounded by the zona pellucida. In a growing follicle of medium-size, two ova are noticed separately, each surrounded by the granulosi layer. The orum often shows a fine figure with Best's staining: The germinal spot is red. the germinal vesicle blue and the vitellus red, containing glycogen and glycogen-like substance. These substances are richer in amount than found in the rabbit, and are biased toward the deeper part of the ovary. The zona pellucida is stained as a homogeneous line with Best's solution.

Corpus luteum.

The ovaries of the mouse contain more numerous corpora lutea than those of the rabbit. Concerning the phenomena of their development and retrogression, the two kinds of animals show no essential difference, but a little difference exists in the different parts of the corpus luteum. The granulosa cells of the mouse after rupture are converted into lutein cells by their hypertrophy only, contrary to the polygonal cells of the theca interna, which degenerate during the early period of the corpus luteum formation. Contrary to what occurs in the rabbit, the roung corpus luteum in the mouse shows often a vesicular appearance, the liquor accumulating in its central cavity owing to the early closure of the orifice made by rupture. The fluid of this cavity is usually negative for Best's stain, although the leucocytes found in the large hemorrhage, not in the fluid of this cavity, contain usually glycogen in their cytoplasm. The spindle-shaped cells of the theca interna and the exterma, after rupture, penetrate into the granulosa laver with capillaries of the theca interna, and form the comnective tissue reticulum among the lutein cells, and some of them make up the central connective tissue nucleus of the corpus luteum. The majority of the lutein cells, during the period of the corpus luteum retrogression, disappear by their fatty degeneration, and a part of them are converted into pigment cells as those of the rabbit. The 
commective tissue reticulum, the central nucleus, the capsule and the blood ressels of the corpus luteum disappear earlier than in the rabbit.

The glycogen of the corpus luteum ovulationis appears minutely in the lutein cells within a day after ovalation, increases gradually in the growing corpora lutea of 2 days old (Fig. 3), and reaches its maximal amount in the young corpora lutea of 3 or 4 days old. It is universally distributed in the whole corpus luteum, not restricted within the central part nor within the peripheral part. The capillary walls among the lutein cells contain also a little glycogen in these stages. Fully grown corpora lutea usually contain no glycogen. Glycogen reappears minutely in some large vacuolated lutein cells of the degenerating corpora lutea, but never in their pigment cells. In the corpus luteum graviditatis, glycogen begins to appear in the young corpora lutea 38 hours after copulation, increases gradually to reach its maximal amount in the period from $s$ to 10 days of gestation, then decreases rapidly and disappears soon afterward. It reappears, however, in some degenerating lutein cells about 15 days after parturition, but never in the pigment cells. Groups of degenerating lutein cells with pycnotic nuclei which contain glycogen can scarcely be met with in the mouse. There is no glycogen to be found in the connective tissue reticulum, nor in the cavity of the blood vessels. Moreorer, the rnast cells can never be seen containing granules which react positive to Best's solution. The glycogen content in the lutein cells of the mouse is smaller in amount than that of the rabbit, although it shows similar appearance in the lutein cells of the both animals.

A tretic follicle.

Atretic follicles are found in smaller number than in the rabbit, and the majority of them are under the moderate size. Some of the mature follicles, fall, however, into atrophy in the depth of the ovaries. During the late stage of gestation, the follicles larger than medium size are converted into the grown interstitial gland by their atrophy.

1. The theca externa. Some atrophy of the smaller follicles, represented by the small cystic atrophy, takes place as in the rabbit. By the atrophy of the follicles larger than the medium size, the polygonal cells usually show a little growth, in spite of the degeneration of the orum and the granulosa layer. Meanwhile, a part of the spindle-shaped cells of the theca externa penetrate in among the polygonal cells, and surround the latter as a lobe together with those of the theca interna. Therefore, the theca externa becomes gradually thinner and disappears with the advancement of the follicular atrophy. Glycogen is never found in this laver. 
On the Appearance of Glycogen in the Female Reproductive Gilands of Rodents. 451.

2. The theca interna. The polygonal cells of this layer are usually. converted into the young interstitial gland cells by growth. The spindleshaped cells penetrate into the granulosa layer with cell divisions through the basement membrane, and usually construct small central connective tissue nucleus at the place where the ovum and the granulosa cells were noticed formerly, although the majority of them surround the several interstitial gland cells. The capillaries in this layer increase also to insure sufficient circulation in the interstitial gland. Glycogen sometimes appears in the polygonal cells during the period of gestation and of non-gestation.

3. The basement membrane. In the small atretic follicles the membrane remains as a concentric line of delicate connective tissue fibers, and it often shows similar appearance in the atretic follicles of medium size or larger. When it increases in thickness, it is evenly stained reddish with Best's solution as in the case of rabbit.

4. The membrana granulosa. Usually the atrophy sets in with the disappearance of the cell divisions and the degeneration of the granulosa cells facing the antrum folliculi. These degenerative processes begin synchronously with those of the ova in the small follicles, although they begin, in general, earlier or later than those of the ova in the larger follicles. For instance, some ova show an almost normal appearance, when the majority of the granulosa cells have disappeared. On th" contrary, granulosa cell; show the sign of increasing with cell divisions as those of the normal follicles, although the ovum has degenerated within the zona pellucida without any cells of the corona radiata remaining. The nuclei of the granulosa cells show pycnosis or caryorrhexis besides other changes which were noted in the rabbit. Histiocytes of various size are also found; smaller types usually appearing in the early period of atrophy and the larger ones in late stage, as in the rabbit. The larger histiocytes often show phagocytic phenomenon. Glycogen rarely appears in a small amount in the degenerating granulosa cells (Fig. 4). Histiocytes contain no glycogen, but when they phagocytose what appear to be degenerated granulosa cells a small quantity of this substance may be demonstrated.

5. The liquor folliculi. There is no cystic atrophy of the follicle, as the liquor folliculi is gradually absorbed, although a large quantity of it accumulates in the Graafian follicle. It shows dusty or granular appearance and is stained reddish with Best's solution.

6. The egg. The nucleus of the ovum in the process of degeneration becomes unstainable and the cytoplasm granular. Histiocytes 
penetrats into the space between the zona pellucida and the ovum in the early stage of atrophy. The ovum is often divided into two or more cells after it has produced the polar bodies within the zona pellucida. This phenomenon can be observed also in the non-fertilized ova expelled in the Fallopian tube. The ovum exists rarely in the central cavity of the ovary (cf. my former paper entitled 'On the retrogression of the corpus luteum of the mouse'). This may be caused by the destruction of the follicular wall in the process of the extension of the central cavity, probably due to the digestive enzyme of the fluid contained in it. The ovum and the fluid accumulated in the central cavity contain no glycogen. However, the granulosa cells extruded into the central cavity contain a little of this substance. The appearance of glycogen in the ova of the atretic follicles is more frequent and notable than in the rabbit. The exp lled ova and granulosa cells in the tube also contain granules of glycogen. Glycogen appears also in the epithelial cells of the mucous membrane of the tube at their free or basal portion, when the ovum or the granulosa cells pass by them. The rona pellucida is thickened and twisted, and is stained homogeneously reddish with Best's carmine.

Interstitial gland.

During the non-pregnant period, there is but a little young interstitial gland among the corpora lutea and the follicles which form the major portion of the ovarian tissue, although grown interstitial glands are found sometimes. They are small, containing small round or oval nuclei deeply stained with hematoxylin, and have little cytoplasm. Some of these young interstitial gland cells are difficult to distinguish from the stroma connective tissue cells, owing to the fact that the latter also contains many capillaries. In such a case, they may be distinguished by the substance stained with sudan III or osmic acid which is found in the young interstitial gland cells. During the pregnant period, many grown interstitial glands are found, which closely resemble the corpora lutea. These two can be distinguished, however, by the external capsule of the corpus luteum and fewer connective tissue cells and blood vessels of the interstitial gland. Moreover, the grown interstitial gland cells can be distinguished from the grown lutein cells by their smaller size, by being less deeply stained with eosin, by smaller amount of substance stained with sudan III or osmic acid, and by the occasional occurence of mitosis. During the puerperal period, degeneration of the 
On the Appearance of Glycogen in the Female Reproductive Glands of Rodents.

grown interstitial gland cells is remarkable. Glycogen is noticed many times in the young interstitial gland during the non-pregnant stage. The grown and the degenerating interstitial gland cells usually show negative reaction for Best's stain.

Table III.

Glycogen in ovaries of pregnant mice.

\begin{tabular}{|c|c|c|c|c|c|c|c|c|c|c|c|c|c|c|c|}
\hline & bu & 1 & 2 & 3 & & & 6 & 7 & 8 & 9 & 10 & 11 & 12 & 13 & 14 \\
\hline & ation. & $3 \mathrm{~h}$ & $8 \mathrm{~h}$ & & & & & $\begin{array}{l}80 \\
\text { h }\end{array}$ & $6 \mathrm{~d}$ & $8 \mathrm{~d}$ & $\begin{array}{l}10 \\
d\end{array}$ & & & $\begin{array}{l}10 \\
d\end{array}$ & $\mathrm{~d}$ \\
\hline & al epithelium. & - & & & & & & - & & - & 一 & & - & - & - \\
\hline & roma connective tissue. & - & - & & & & - & - & & - & - & - & - & - & - \\
\hline & of hilum. & - & - & & & & - & - & - & - & - & - & - & - & - \\
\hline & uscle of blood vessels.' & + & - & + & & & + & + & \pm & + & + & - & - & - & - \\
\hline & Theca externa. & - & - & - & & & - & - & - & - & - & - & - & - & - \\
\hline & $"$ interna. & - & - & - & & & - & - & - & - & - & - & - & - & - \\
\hline & Basement membrane. & - & - & - & 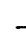 & & - & - & - & - & - & - & - & - & - \\
\hline & Membrana granulosa. & - & - & - & & & - & - & - & - & - & - & - & - & - \\
\hline & Ovum. & + & + & + & & & + & + & + & + & + & + & + & + & + \\
\hline & Young lutein cells. & · & . & - & & & + & + & - & . & • & $\cdot$ & · & $\cdot$ & - \\
\hline & Grown & . & - & & & & - & . & \pm & + & H & \pm & - & - & - \\
\hline & (Degenerating & - & . & & & & $\cdot$ & - & $\cdot$ & - & . & - & . & $\cdot$ & - \\
\hline & Young lutein cells. & . & . & & & & - & . & $\cdot$ & • & $\cdot$ & • & • & $\cdot$ & 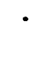 \\
\hline & " Grown ", " & - & - & - & & & - & \pm & - & \pm & - & $\cdot$ & - & - & $\cdot$ \\
\hline & " & - & . & - & & & - & - & - & \pm & $\cdot$ & - & - & - & - \\
\hline & (Theca externa. & - & - & - & & & - & - & - & - & - & - & - & - & - \\
\hline$\stackrel{ن}{ت}$ & $"$ interna. & - & - & & & & - & - & - & \pm & + & - & - & - & - \\
\hline & Basement membrane. & - & - & & & - & - & - & - & - & - & - & - & - & - \\
\hline & Membrana granulosa. & - & - & - & & & - & - & + & + & - & - & - & - & - \\
\hline$\frac{3}{4}$ & Ovun. & + & + & + & & + & + & + & + & + & + & + & + & + & + \\
\hline & (Histiocytes. & - & - & - & & - & - & - & - & - & - & - & - & - & - \\
\hline 馬 & $\begin{array}{l}\text { Young interstitial } \\
\text { gland cells. }\end{array}$ & \pm & - & - & & - & - & - & - & - & - & \pm & - & - & - \\
\hline & $\left\{\begin{array}{l}\text { Grown } ", " ~ \\
\text { Degenerating, } \\
", " ~\end{array}\right.$ & - & $\cdot$ & - & & & . & · & . & . & . & \pm & - & - & - \\
\hline
\end{tabular}


Table

Glycogen in ovaries of

\begin{tabular}{|c|c|c|c|c|c|c|c|c|c|c|}
\hline Mouse number. & 1 & 2 & 3 & 4 & 5 & 6 & 7 & 8 & 9 & 10 \\
\hline Time after parturition. & $1 \mathrm{~d}$ & $2 \mathrm{~d}$ & $3 \mathrm{~d}$ & $4 d$ & $5 \mathrm{~d}$ & $6 \mathrm{~d}$ & $7 \mathrm{~d}$ & $8 \mathrm{~d}$ & $9 \mathrm{~d}$ & $10 \mathrm{~d}$ \\
\hline Germinal epithelium. & - & - & - & - & - & - & - & - & - & - \\
\hline ective tissue. & _ & - & - & - & - & - & - & - & - & - \\
\hline Muscle of hilum. & - & + & - & - & - & - & - & - & - & - \\
\hline Muscle of blood vessels. & - & - & + & \pm & - & - & - & - & - & \pm \\
\hline Theca externa. & - & - & - & - & - & - & - & - & - & - \\
\hline$\dot{\doteqdot} \quad, \quad$ interna. & - & - & - & - & - & - & - & - & - & - \\
\hline$\fallingdotseq$ Basement membrane. & - & - & - & - & - & - & - & - & - & - \\
\hline Membrana granulosa. & 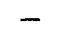 & - & - & - & - & - & - & - & - & - \\
\hline Ovum. & + & + & \pm & \pm & + & \pm & + & \pm & + & \pm \\
\hline$\left\{\begin{array}{l}\text { Young lutein cells. } \\
\text { Grown }\end{array}\right.$ & . & \pm & + & \pm & + & $\begin{array}{l}+ \\
.\end{array}$ & $\dot{+}$ & $\dot{-}$ & $\dot{r}$ & 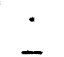 \\
\hline 作 & + & $\therefore$ & $\dot{.}$ & . & $\dot{.}$ & . & $\stackrel{I}{.}$ & . & . & . \\
\hline Young lutein cells. & & - & 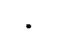 & . & . & . & . & . & - & - \\
\hline 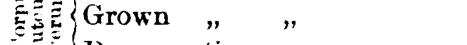 & - & - & - & - & - & - & - & - & - & - \\
\hline Degenerating " & 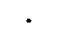 & $\cdot$ & - & - & . & . & . & - & . & . \\
\hline$\dot{\Xi}$ Theca externa. & - & - & - & - & - & - & - & - & - & - \\
\hline , interna. & - & - & - & - & - & - & - & - & - & - \\
\hline $\bar{\Xi}$ Basement membrane. & - & - & - & - & - & - & - & - & - & - \\
\hline Membrana granulosa. & - & - & - & + & - & + & - & + & + & + \\
\hline Or Ovum. & + & + & + & + & $H$ & + & + & + & + & + \\
\hline (Histiocytes. & - & - & - & - & - & \pm & - & \pm & - & - \\
\hline Young interstitial gland cel & - & - & + & - & - & - & - & - & - & - \\
\hline$\left\{G_{\text {rown }}\right.$ & - & 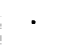 & 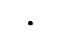 & 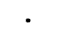 & - & - & . & - & - & $\cdot$ \\
\hline$=\bar{x}$ Degenerating $"$, & - & - & - & - & - & - & 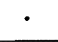 & $\cdot$ & & \\
\hline
\end{tabular}

\begin{tabular}{|c|c|c|c|c|c|c|c|c|c|c|}
\hline Mouse number. & 29 & 30 & 31 & 32 & 33 & 34 & 35 & 36 & 37 & 38 \\
\hline Time after parturition. & $29 \mathrm{~d}$ & $30 \mathrm{~d}$ & $31 \mathrm{~d}$ & $32 \mathrm{~d}$ & $33 \mathrm{~d}$ & $34 \mathrm{~d}$ & $35 \mathrm{~d}$ & $36 \mathrm{~d}$ & $37 \mathrm{~d}$ & $38 \mathrm{~d}$ \\
\hline Germinal epithelium. & - & - & - & - & - & - & - & - & - & - \\
\hline Stroma conı & - & - & - & - & - & - & - & - & - & - \\
\hline Mruscle of hilum. & - & - & - & - & - & - & - & - & - & - \\
\hline Muscle of blood ressels. & - & + & + & - & - & + & + & + & + & - \\
\hline Theca externa. & - & - & - & - & - & - & - & - & - & - \\
\hline$" \quad$ interna. & - & - & + & - & - & - & - & - & - & - \\
\hline Basement membrane. & - & - & - & - & - & + & - & - & - & - \\
\hline Membrana granulosa. & 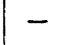 & - & - & - & - & - & - & - & - & - \\
\hline Ovum. & + & + & + & + & + & - & \pm & + & + & \pm \\
\hline Young lutein cells. & & \pm & $\cdot$ & $\cdot$ & \pm & - & - & . & - & + \\
\hline 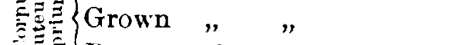 & - & - & - & - & - & · & - & - & - & - \\
\hline 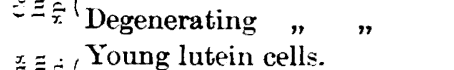 & - & - & + & . & \pm & . & - & - & . & - \\
\hline 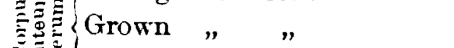 & 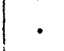 & 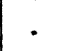 & . & . & . & - & . & - & : & . \\
\hline$=\Xi$ (Degenerating $"$ & 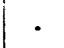 & 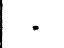 & $\cdot$ & . & . & + & $\cdot$ & . & . & . \\
\hline$\stackrel{\text { Theca externa. }}{ }$ & - & - & - & - & - & - & - & - & - & - \\
\hline$\#$ interna. & 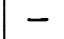 & \pm & + & - & - & - & - & - & - & - \\
\hline$\Xi /$ Basement membrane. & & - & - & - & - & + & - & - & - & - \\
\hline Membrana granulosa. & & + & - & - & - & - & - & - & - & - \\
\hline Ovum. & 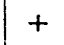 & + & + & + & + & + & \pm & + & H & + \\
\hline (Histiocyter. & - & - & 一 & - & - & - & - & - & - & - \\
\hline (Young interstitial gland cells. & - & - & + & - & - & + & - & - & - & - \\
\hline 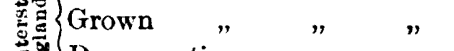 & - & - & • & $\cdot$ & • & - & $\cdot$ & - & · & $\cdot$ \\
\hline$E^{\Delta /}$ Degenerating $\quad " \quad$ & - & - & ${ }^{\circ}$ & • & - & $\cdot$ & . & $\cdot$ & & $\cdot$ \\
\hline
\end{tabular}


On the Appearance of Glycogen in the Female Reproductive Glands of Rodents. 455

IV.

non-pregnant mice.

\begin{tabular}{|c|c|c|c|c|c|c|c|c|c|c|c|c|c|c|c|c|c|c|}
\hline 11 & 12 & 13 & 4 & 15 & 16 & 17 & 18 & 19 & 20 & 21 & 25 & & 23 & 24 & 25 & 26 & 27 & 28 \\
\hline 11 & $12 \mathrm{~d}$ & $13 \mathrm{~d}$ & $14 \mathrm{~d}$ & $15 \mathrm{~d}$ & $16 \mathrm{~d}$ & $17 \mathrm{~d}$ & $18 \mathrm{~d}$ & $19 \mathrm{~d}$ & $20 \mathrm{~d}$ & $21 \mathrm{C}$ & 22 & & $3 \mathrm{~d}$ & $24 \mathrm{~d}$ & $25 \mathrm{~d}$ & $26 \mathrm{~d}$ & $27 \mathrm{~d}$ & $28 d$ \\
\hline- & - & - & - & - & & & & - & - & & & & - & - & - & - & - & - \\
\hline - & - & & & & & & & - & & & & & & - & & 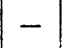 & 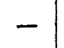 & - \\
\hline- & - & & - & & & & & - & 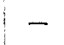 & & & & & - & & - & - & \pm \\
\hline- & - & & - & + & + & - & & - & + & & & & & - & & + & + & + \\
\hline- & 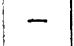 & & - & & & - & & - & + & & & & & & - & - & & - \\
\hline- & - & - & 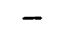 & & - & - & & - & + & & & & & & - & \pm & \pm & \pm \\
\hline- & - & - & 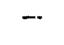 & & - & - & - & - & - & & & & & - & - & - & - & - \\
\hline- & - & - & - & & - & - & - & & - & & & & 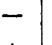 & - & - & - & - & - \\
\hline- & + & + & - & + & + & - & - & + & + & & & & 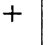 & + & + & + & + & + \\
\hline & - & & . & & & & & 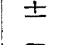 & +1 & & & & $\cdot$ & & - & + & + & . \\
\hline & . & . & 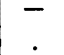 & - & . & 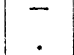 & . & - & - & . & & & - & - & - & -1 & - & - \\
\hline & & & & & & & & & & & & & & & . &. & . & - \\
\hline & - & & & 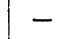 & & & & & . & & & & & & & . & . & \\
\hline & & & - & & - & \pm & - & & + & & & & 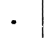 & . & . & . & . & . \\
\hline & - & - & & - & - & & - & - & - & & - & & - & - & - & - & - & - \\
\hline & - & - & & \pm & - & $t$ & - & - & + & & \pm & & \pm & - & - & -1 & - & \pm \\
\hline 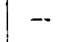 & - & - & & & - & 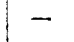 & - & - & - & - & 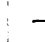 & & - & - & - & - & - & - \\
\hline \pm & + & + & - & & + & & + & & - & & & & - & - & - & - & - & - \\
\hline+ & + & + & + & + & - & & + & & + & & t & & + & + & + & + & + & + \\
\hline- & - & - & & & & & - & & & & & & - & - & - & -1 & - & - \\
\hline- & - & - & - & + & - & 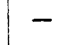 & - & 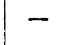 & + & 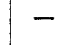 & + & & \pm & - & - & \pm & + & \pm \\
\hline & & . & & & & & & & . & & & & $\cdot$ & . & $\cdot$ & $\cdot$ & $\cdot$ & • \\
\hline - & . & - & . & $\therefore$ & ${ }^{\circ}$ & ${ }^{\circ}$ & $\cdot$ & 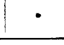 & $\cdot$ & 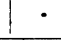 & . & & $\cdot$ & - & $\cdot$ & - & -1 & • \\
\hline 3 & 40 & 41 & 42 & 43 & 44 & 45 & 46 & 47 & 48 & 49 & 5 & & 51 & 52 & 53 & 54 & 55 & 56 \\
\hline $39 \mathrm{~d}$ & $40 \mathrm{~d}$ & $41 \mathrm{~d}$ & $42 \mathrm{~d}$ & $43 \mathrm{~d}$ & $44 \mathrm{~d}$ & $45 \mathrm{~d}$ & $48 \mathrm{~d}$ & $50 \mathrm{~d}$ & $53 d$ & 56 & 59 & & $61 \mathrm{~d}$ & $63 \mathrm{~d}$ & $64 \mathrm{~d}$ & $66 \mathrm{~d}$ & $68 \mathrm{~d}$ & $70 \mathrm{~d}$ \\
\hline - & - & - & - & 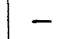 & - & & - & & 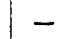 & & & & - & - & - & - & - & - \\
\hline & & & & & & & & & & & & & & - & & & - & - \\
\hline- & & & & & & & - & & - & & & & - & - & - & - & - & - \\
\hline+ & - & & & & \pm & & & & - & & t & & + & - & - & \pm & \pm & + \\
\hline & - & - & & & & - & & & - & & - & & - & - & - & - & - & - \\
\hline & - & & & & & & & & - & & 7 & & + & - & - & - & - & - \\
\hline & - & & & & & & & & - & & - & & - & $1-$ & - & - & - & - \\
\hline & - & & & & & & & & - & & - & & - & - & - & - & - & - \\
\hline & \pm & + & + & + & & & & & + & & & & + & + & + & + & + & + \\
\hline & - & + & & & & & & & & & & & \pm & & & + & . & \\
\hline 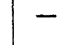 & - & - & & - & & & & 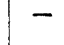 & \pm & - & & & - & $1-$ & - & - & \pm & \pm \\
\hline & + & . & & - & $=$ & - & & & - & . & 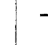 & & $\cdot$ & . & -1 & - & $\cdot$ & \\
\hline & 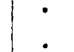 & 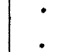 & & 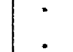 & & & & & & & & & $\cdot$ & $\cdot$ & $\cdot$ & $\cdot$ & . & \\
\hline & & & & & & & & & & & & & $\cdot$ & & & & • & \\
\hline & - & - & & & - & & & & - & - & - & & - & & & & - & \\
\hline & - & - & & & - & - & - & - & - & & - & & - & - & - & - & -1 & - \\
\hline & - & - & & - & - & - & - & - & - & 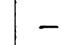 & - & & - & - & - & - & - & - \\
\hline . & - & + & & - & - & - & - & - & + & & 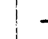 & & - & - & + & - & - & - \\
\hline- & $t$ & + & & + & + & + & + & + & & + & $=$ & & \pm & + & +1 & + & + & + \\
\hline . & 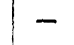 & - & - & - & & - & - & - & - & - & - & & -1 & $1-$ & - & - & - & - \\
\hline- & - & 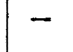 & - & + & \pm & - & - & - & - & - & 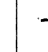 & & - & - & - & - & + & + \\
\hline & . & & & & & & & • & • & & & & & & & • & $\cdot$ & \\
\hline
\end{tabular}




\section{Rat.}

Six ovaries obtained from alult rats closely resembled those of adult mice in structure, except the absence of the central cavity of the ovary and its larger size in the former.

Germinal epithelium.

This is a layer of squamous and columnar epithelial cells, containing no glycogen.

Stroma connective tissue.

The connective tissue of the cortex is small in amount, existing among corpora lutea, follicles, and interstitial glands. The tunica albuginea is scarceiy formed. In the medulla it can be noticed around the blood vessels. No glycogen appears in the spindle-shajerl connective tissue cells.

Smooth muscle fibers.

These constitute a part of the hilum and the wall of the blood vessels as in the mouse. Glycogen is noticed abundantly in the hilum directly after parturition (Fig. 5), but not during gestation or in the normal period. In the walls of blood vessels, glycogen globulets are found in the oviry directly after parturition only.

Follicle.

Oraries contain many follicles in rarious stages of development. The differentiation of the theca interna and the accumulation of the liquor folliculi take place at about the same time as in the mouse.

1. The theca externa. In the mature follicle, it is composed of 2 or 3 layers of spindle-shaped cells in concentric arrangement, and shows no glycogen content.

2. The theca interna. This layer consists of polygonal and spindle-shaped cells in the mature follicle, as that of the mouse. Among these cells the capillary network is well developed. A few glycogen granules are found in the polrgonal cells directly after parturition.

3. The basement membrane. There is an unstainable zone with Best's staining, between the theca interna and the membrana granulosa.

4. The membrana granulosa. The course of the development of this layer is the same as in the mouse, and it is composed of several layers of epithelial cells arranged radially in the mature follicle. A part of this layer shows also a rounded or cone-shaped projection into the antrum folliculi, i.e., the cumulus oophorus. The granulosa cells contain usually no glycogen. 
On the Appearance of Glycogen in the Female Reproductive Glands of Rodents. 457

5. The liquor folliculi. This fluid begins to accumulate when the differentiation of the theca interna appears. The so-called Call-Exner bodies are absent. It is sometimes deeply stained as fine granules, although it usually remains unstained (Fig. 6).

6. The egg. Glycogen of the ovum is, in general, gradually increased in amount as the primitive follicle matures (Fig. 6).

Corpus luteum.

Corpora lutea are found in a large number, and all of them are in the grown stage. The corpus luteum is clearly marked off from other surrounding tissues by the fibrous coat, and the lutein cells are arranged mostly radially from the connective tissue nucleus sustained by the connective tissue and blood-vessels. Glycogen is noticed neither in the lutein cells, in the connective tissue reticulum, nor in the blood vessels.

Atretic follicle.

There are various degrees of atretic follicles in the ovaries, but no cystic atrophy of the larger follicles is present, although many cases of small cystic atrophy are noticed.

1. The theca externa. In the small cystic atrophy, this layer constitutes the wall of the cyst; but in the follicle larger than medium size, it decreases in its thickness and finally disappears by its migration inward and by the enlargement of the polygonal cells of the theca interna. Spindle-shaped cells of this layer show no glycogen.

2. The theca interna. The spindle-shaped cells and the capillaries of this layer are increased, coincident with the growth of the polygonal cells, the former surrounding several of the latter cells. Furthermore, the spindle-shaped cells penetrate through the basement membrane into the central part to form the connective tissue nucleus. This central nucleus of the atretic follicle is usually small in size, but it sometimes becomes a large nucleus of connective tissue cells, arranged irregularly or concentrically, surrounding a small central cavity. Glycogen appears in abundance in the polygonal cells directly after parturition.

3. The basement membrane. This shows the same relation as that of the mouse, exhibiting the appearance of the normal follicles or of the twisted thick band, stained homogeneously reddish with Best's solution.

4. The membrana granulosa. Some of the atretic follicles show the wandering inward of a number of histiocytes. The phenomenon of atrophy of this layer agrees with that in the mouse. Glycogen appears 
neither in the degenerating granulosa cells nor in the various sized histiocytes.

5. The liquor folliculi. This accumulates relatively in a large quantity in the antrum folliculi, although less than in the rabbit. It is often stained reddish with Best's solution.

6. The egg. Histiocytes are often found in the space between the ovum and the zona pellucida. The ovum usually contains glycogen or glycogen-like substance in the vitellus, especially richly in the ovum which has produced the polar body or divided into two or more cells within the zoma pellucida, showing the homogeneous, reddish colour after Best's stain.

\section{Table V.}

Interstitial gland.

Glycogen in ovaries of rats

In the puer-
perium, young, grown, as well as degenerating inter. stitial gland cells are observed; although in the pregnant period, young and grown types, and in the non-pregnant, young form only are seen. These cells exist throughout the cortex among the corpora lutea and the follicles. Glycogen is noticed only in young interstitial gland cells directly after parturition.

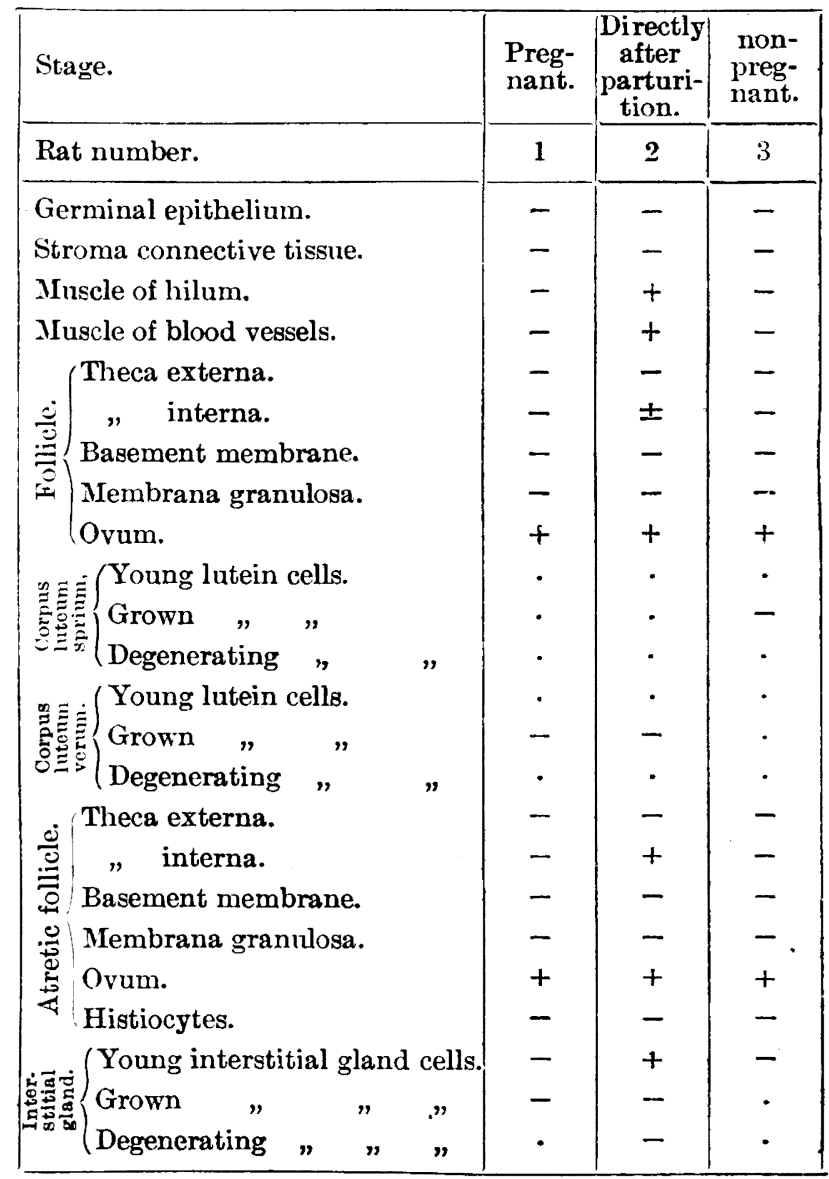




\section{Guinea-pig.}

All the ovaries of the guinea-pigs are obtained from the adult in pregnant and non-pregnant periods.

Germinal epithelium.

This layer is composed of epithelial cells containing no glycogen either in pregnant, or in non-pregnant stage.

Tunica albuginea and stroma connective tissue.

The connective tissue is best developed in guinea-pigs among the animals examined. The tunica albuginea is composed of several layers of closely packed connective tissue cells, and is often stained reddish with Best's solution. The stroma connective tissue is rich in quantity both in the medulla and in the cortex; and it completely surrounds the corpora lutea and the interstitial gland separately, never permitting their direct contact with one another. The spindle-shaped connective tissue cells often contain glycogen.

Smooth muscle fibers.

These belong to the hilum and the walls of the blood vessels. The muscle fibers of the former are rich in glycogen, without fail in all the stages of gestation and non-gestation.

Follicle.

Some ovaries show a layer of primitive follicles beneath the tunica albuginea. I have not met with a mature follicle, although various stages of growing follicles are found in a large number. The differentiation of the theca interna is closely coincident with the first appearance of the liquor folliculi, as seen in the mouse and in the rat.

1. The theca externa. Here several layers of cells are arranged concentrically. The inner side of this layer is clearly limited from the theca interna, but the outer side is not so well defined from the ovarian stroma. The connective tissue cells of this layer often show glycogen in globulet form.

2. The theca interna. This is a mixed layer of polygonal cells and spindle-shaped cells; latter being connected with the theca externa and running among the former cells diagonally to reach the basement membrane and then running along this membrane. The transitional forms of both cells are often found, although mitotic divisions are scarce among the polygonal cells. The capillary network is also noticed in this layer. Polygonal cells seldom contain glycogen granules. 
3. The basement membrane. This appears as an unstainable zone between the theca interna and the membrana granulosa with Best's solution.

4. The membrana granulosa. In the Graafian follicle, the granulosa cells are small, round or oval, with many cell divisions. Glycogen is not found in any of the cells.

5. The liquor folliculi. In the Graafian follicle, this fluid accumulates in a moderate quantity, and is either scarcely stained or stained as fine granules with Best's stain. The so-called Call-Exner bodies are never to be found.

6. The egg. Glycogen is scarcely met with in the ovum.

Corpus luteum.

The young corpus luteum ovulationis is rich in glycogen which appears in the cytoplasm of the lutein cells (Fig. 7). The corpus luteum graviditatis and ovulationis in fully developed state seldom contain glycogen. The corpus luteum graviditatis in retrogression is also poor in glycogen.

Atretic follicle.

In the guinea-pig, there is no cystic atrophy of the larger follicles though small cystic atrophy is often found.

1. The theca externa. This constitutes the wall of the small cyst or the fibrous coat of the interstitial gland. Hence, the glands coming from numerous atretic follicles are confined within these coats, never coming in contact with one another as seen in the three species of animals above described. A part of the spindle-shaped cells of this layer show, however, the wandering into the theca interna. These spindle-shaped cells often contain a little glycogen.

2. The theca interna. At the time of the atrophy of the Graafian follicles, the polygonal cells of this layer are converted into young interstitial gland cells. With this change, the spindle-shaped cells among them come to surround several interstitial gland cells with those of the theca externa. Capillaries and the spindle-shaped cells show the same arrangement. The spindle-shaped cells penetrate, furthermore, into the antrum folliculi where they form the central connective tissue nucleus. Glycogen is often noticed in the polygonal cells.

3. The basement membrane. The structure of the membrane is normal or takes the form of thick hyaline band; the latter is stained homogeneously reddish with Best's solution. 
On the Appearance of Glycogen in the Female Reproductive Glands of Rodents. 461

4. The membrana granulosa. The atrophy of this layer extends gradually from the central to the peripheral parts as in other animals. The feature of the atrophy is chiefly chromatolysis. The degenerated cells are absorbed, being liquefied or phagocyted by histiocytes which appear in the antrum folliculi. The degenerating granulosa cells show a little glycogen.

5. The liquor folliculi. It seems as if there is a cystic atrophy of the follicle, as the liquor folliculi is moderately rich in quantity, and its absorption is very slow. The so-called Call-Exner bodies are never met with in the atretic follicle. The fluid is often stained red with carmine.

6. The egg. The ova, especially in the state of maturation division or divided into two or more cells, contain much glycogen or glycogenlike substance. The histiocytes often found between the ovum and the zona pellucida stained homogeneously reddish with carmine, contain usually no glycogen.

Interstitial gland.

The ovaries of the guinea-pig contain much interstitial gland tissue. The latter is usually divided off by the fibrous coat and the well developed stroma connective tissue. All the interstitial glands exist, therefore, separately in the oval territories, their long axis being directed from the germinal epithelium to the medullar portion. Their central nuclei are the largest in size among the three species of animals. Interstitial gland cells are of young type with small round nuclei rich in chromatin and with little cytoplasm. Glycogen is sometimes found richly in the young interstitial gland cells (Fig. 8), but poorly in the connective tissue cells of the central nucleus.

Table VI.

Glycogen in ovaries of guinea-pigs.

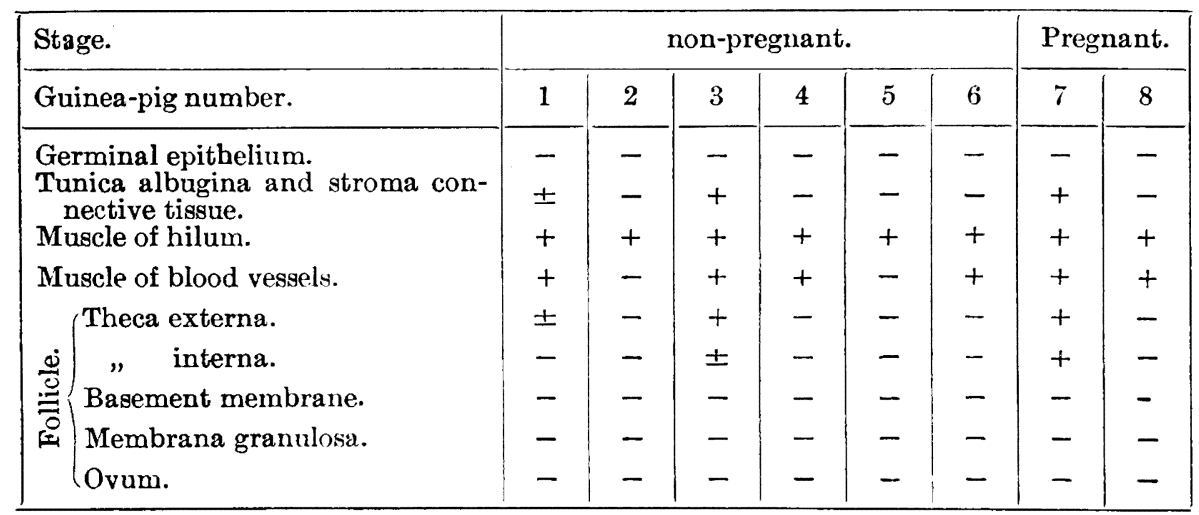


Table VI.

Continued.

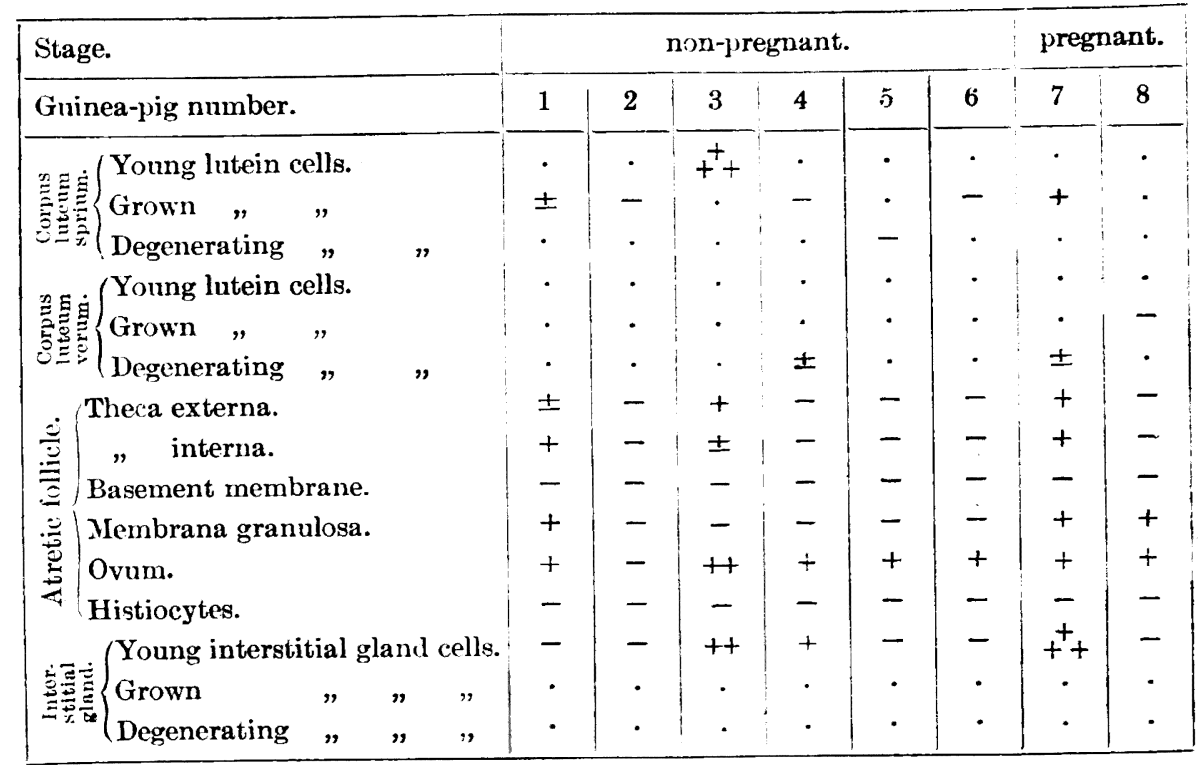

\section{Recapitulation and Discussion.}

\section{A. Germinal epithelium.}

The ovaries of the embryonal structure containing no primordial follicle, are covered by the germinal epithelium consisting of stratified epithelial cells. This is clearly seen even in the ovaries of a rabbit 9 days after birth. These epithelial cells contain fine glycogen granules especially in their basal parts. The germinal epithelium of the adult ovary is, however, composed of a layer of columnar, cubical or squamous cells, and generally contains no glycogen.

The above description is exactly opposite to that of Goldmann who sairl "Und doch muss das Glykogen erst secundär in das Eiplasma gelangen, da weder das Keimepithel noch das Plasma der Primordialeier die histochemische Reaktion auf Glykogen ergiebt".

\section{B. Tunica albuginea and stroma connective tissue.}

Both the tunica albuginea and the stroma connective tissue are originated from the mesenchyme, but they are a little different morphologically.

The tunica albuginea is absent during the embryonal and suckling stages, developing gradually with the advancement of the age, and is 
On the Appearance of Glycogen in the Female Reproductive Glands of Rodents. 463

very different according to animals even in the adult stage. In the rabbit and the guinea-pig, it is markedly developed, and its cells are more elongated, more closely packed and containing more fibers among them than those of the stroma connective tissue. In the mouse and the rat, there is total absence of this layer in this meaning. 'The cells of this layer contain usually no glycogen in any stage, except a little contained in the adult guinea-pig.

'The stroma connective tissue in the ovaries of embryos and sucklings forms a small medullar portion and small twigs of it in the cortical portion. It is very different according to different animals. In the guineapig, it is largest in amount, surrounding the follicles, the corpora lutea and the interstitial glands in the cortex, and existing around the blood vessels in the medulla. In the rabbit, the stroma of the cortex is relatively little, surrounding several interstitial gland cells or combining the tunica albuginea and the medullary connective tissue, except the theca externa of the follicle or the capsule of the corpus luteum. In the medulla, the stroma cells are relatively rich in amount, and are loosely arranged. In the mouse and the rat, the stroma is scanty existing around the blood vessels, among the follicles, the corpora lutea and the interstitial glands. Glycogen is not found, in general, in the stroma cells, except a little in the ovaries of the adult guinea-pig. Ando has stated, however, that glycogen appears in the comnective tissue cells of the embryonal ovaries of the cat and the dog.

\section{Smooth muscle fibers.}

The smooth muscle fibers of the ovary are of two kinds; one is concerned in the formation of the hilum, and the other is connected with the walls of the blood vessels. The smooth muscle fibers of the hilum exist without fail, although their amount is different in different animals and individuals. Their glycogen contents are also different in various animals. Guinea-pigs contain the largest amount in the fibers. In the rabbit, it is contained markedly in the early period of gestation and sometimes a little in the non-pregnant period. In the mouse and the rat, on the contrary, no glycogen is contained except in a case of puerperium in both animals. The size of the blood vessels corresponds to that of the ovaries, the rabbit ovary being the largest. Glycogen is found larger in amount in the arteries than in the veins. It is often seen in the guinea-pig and the mouse, and also in the rat directly after parturition. In the rabbit, it can never be seen in the non-pregnant period, but it can be found in the early period of gestation. 
The state of glycogen distribution in the smooth muscle fibers agrees with the descriptions of previous writers, showing fine granules or globulets near both poles of the nuclei or near their sides, never existing in the nuclei. Often thread-like appearance of fine granules is seen biased toward one side of the cytoplasm along its long axis (Fig. 5). The latter feature is clearly due to the action of the fixing fluid as explained by Fichera.

As to the glycogen in the smooth muscle fibers in the orary, Fichera noticed that glycogen is found in the smooth muscle fibers in the ovary of the healthy dog, but Gierke declared that there is no glycogen in the human and rabbit ovaries. Kalbermatten stated in man and in the rabbit that "In beiden Fällen waren Glykogenfrei die Muskelfasern der Aorta und die grösseren Köperarterien sowie der kleinen Arterien im Parenchym der Nieren und Leber,-wobei auch die Epithelzellen kein Glykogen enthieten; ferner die Muskulatur des Ovariums und des Musculus ciliaris. Hingegen enthielten die kleinen Arterien des Uterus Glykogen in geringerer Menge". Ho noticed, furthermore, as to the significance of the glycogen appearance in the smooth muscle fibers, that "Es scheint wahrscheinlich, dass das Glykogen für den Stoffwecksel der glatten Muskulatur die gleiche Bedeutung hat, wie für den der quergestreiften Muskulatur. Freilich ist es sehr wohl möglich, dass nur die ruhende glatte Muskelfaser Glykogen in morphologisch nachweisbarer Form zu speichern vermag, während bei beständiger funktioneller Inauspruchnahme des Glykogens nicht nachweisbar ist".

Richard described that the smooth muscle fibers of the ovary were glycogen-free as Gierke and Kalbermatten reported, although he noticed that "Meine Beobachtungen am normalen Kaninchen lassen also auf eine ziemlich allgemeine verbreitung des Glykogens in der glatten Muskulatur schliessen, allerdings sind nicht unbedeutende Unterschiede zwischen den Individuen und zwischen den verschiedenen Organen eines Tieres vorhanden". He, furthermore, exerimentally affirmed Kalbermatten's theory that the muscles in action are poor in glycogen. Namely, glycogen appears more frequently in rest than in action in the smooth muscle fibers of the respiratory, alimentary and reproductive organs. As extreme examples, he mentioned that glycogen of the muscular coat of the large intestine increases in amount after the application of atropine, and totally disappears after pilocarpine administration, and the musculus sphincter pupillae contains no or very little glycogen in action, but the amount can be increased by atropine application. The 
On the Ajpearance of Glycogen in the Female Reproductive Glands of Rodents. 465

muscle fibers of the ovary show, however, no glycogen even after the atropine application.

According to these two authors, the glycogen of the smooth muscle fibers is indefinite in its existence, and it appears more frequently during resting stage. But the ovary is usually a glycogen free organ. In my specimens of the ovaries of rodents, however, glycogen appears only during the early period of gestation or puerperium although much of it is found always in the guinea-pig. The ovaries during these two periods show marked hyperemia universally as the other reproductive organs. Hence, the muscle fibers in the ovaries can scarcely be thought to be in the resting stage, and the glycogen may be regarded as serving as nutrients for the action of these rauscle fibers.

Ohashi noticed lately that as the glycogen of the smooth muscle fibers in the uterus of the mouse appears during the middle and late stages of pregnancy, during the period from 2 to 3 days after parturition and during the heat period, glycogen can scarcely be thought to appear in the resting stage of the smooth muscle fibers. Therefore, the point emphasized by both Kalbermatten and Richard may be a condition of glycogen appearance in the muscle. Ohashi's description as to the glycogen appearance in the muscular wall of the uterus generally agrees with my own in the ovarian muscle.

\section{Follicle.}

Ovaries of all animals contain many follicles in various stages of development, from the primordial to the mature, except the guinea-pig which lacks the mature follicles in my preparations.

1. The theca folliculi. The sheath of the primitive follicle is composed of a layer of spindle-shaped connective tissue cells arranged concentrically. As the follicle grows, the sheath gradually becomes thicker and when the sheath grows $3-5$ cells in thickness, the cells of the inner part of this sheath are enlarged in their cytoplasm to be changed into polygonal cells, and then the difference between the theca interna and the externa can be recognized. After this, as the follicle develops, the polygonal cells increase not only by the hypertrophy of the spindle-shaped cells, but also by the mitotic division of the polygonal cells as seen in the rabbit and guinea-pig. The theca interna of the mature follicles contains the spindle-shaped cells, their sheath showing the appearance as described by Honoré, Thomson and others, or the so-called Kölliker's three layers, the stratum fibrosum internum, the stratum medium cellulare and the stratum fibrosum externum, as Cohn, Meyer and others noticed. 
The spindle-shaped cells of the theca externa and interna contain usually no glycogen except in the guinea-pig, in which it is sometimes contained. On the contrary, polygonal cells of the theca interna sometimes contain glycogen granules in their cytoplasm. As they contain, furthermore, substance stained with sudan III in their cytoplasm, glycogen and fat show a coexistence in the polygonal cells. Hitherto, in regard to the function of these cells, some insisted that they serve as a local nutrition, and others that they produce an internal secretion. I can not help taking the former view, owing to the coexistence of $g l y$ cogen and fat in their cytoplasm. Therefore, these cells may perform two kinds of function as Wolz noticed, i. e., they may perform the nutritive function of the eggs in the normal Gra a fian follicles, but may be secretory in the atretic follicles, in which they are converted into the interstitial gland cells.

2. The basement membraue. This is a narrow zone of closely packed connective tissue fibers between the theca interna and the membrana granulosa. It exists in all the follicles from primordial to mature, showing itself as unstainable, homogeneous line after staining with Best's solution.

3. The membrana granulosa. This layer originates from the germinal epithelium. Pflüger's egg tubes and nests of cells consisting of primitive ova and epithelial cells both increasing in number with cell djvisions, contain rarely a little glycogen as seen in the rabbit ovary. When the primitive follicle is formed, its granulosa layer is composed of a layer of squamous cells which surround a single ovum. With the development of the follicle, these cells increase in their heights, showing high columnar shape. But in moderate sized follicles, they diminish in their heights again to become columnar, and then round or oval in shaje. These granulosa cells in the primitive as well as in the mature follicles often show mitotic divisions, and contain no glycogen. Fichera noticed, however, in the ovary of the dog that the many cells of the cumulus oophorus, the granulosa layer and the corona radiata contain glycogen. On the contrary, Goldmann noticed in the mouse and rat that they are negative for glycogen reaction.

t. The liquor folliculi. This fluid begins to accumulate in some parts of the granulosa layer at about the time of the differentiation of the theca interna and externa. The so-called Call-Exner bodies ure found not only in the growing follicles, but also in mature ones in the rabbit, although they are absent in the other three species of animits. As to the formation of the liquor folliculi, there is much divergence of 
On the Appearance of Glycogen in the Female Reproductive Glands of Rodents. 467

opinions as described in my former work entitled "On the origin of the corpus luteum of the mouse". And I believe that it may be formed by the transudation from the blood vessels of the theca interna and the secretion of the granulosa cells especially of the Cal!-Exner bodies. With Best's solution, it is scarcely stained or stained diffuscly or granular and is seen biased toward medullary side. Call-Exner bodies show spherical cavities of reticular structure surrounded by the granulosa cells, and their reticulum is stained also diffusely or granular with carmine. Hence, the liquor folliculi may contain glycogen-like substance.

5. The egg. Many reports can be enumerated as to glycogen found in the orum. Goldmann noticed in the mouse and rat that "Es muss nur als eine auffallende Erscheinung verzeichnet werden, dass wïhrend Glykogen im Plasma des reifenden, des gereiften und geteilten Eies zu finden ist, sein Nachweis in den Follikelzellen der Membrana granulosa des Eies, der \%ona radiata und auch in den Zellkomponenten des Corpus luteum in der Regel fehlschlägt". The figures of his 'reifender Graafscher Follikel' and 'Graafscher Follikel mit Eizelle in 'Teilung begriffen' in his plates, however, may represent the follicles during the early stages of their atrophy, not normal, healthy follicles. Figure 2 of Plate 1, showing his growing follicle of the normal mouse contains no cell division in the granulosa epithelium often scen during the early stages of the atretic follicles. His Figure 3, i.e., his Graa fian follicle, shows a large quantity of liquor folliculi with twisted thread-like appearance, and some swollen granulosa cells with much glycogen. His divided orum containing glycogen is surrounded by the incomplete zona pellucida, lacking, however, the corona radiata and the cumulus oophorus. All the cells of his granulosa layer are arranged concentrically surrounding the antrum folliculi, and its outer-and innermost layers are composed of spindle-shaped cells. His granulosa layer, therefore, closely resemble the theca folliculi, consisting of the three layers of Kölliker. Such a figure may be that of the atretic follicle in which the granulosa layer has disappeared and the ovum is divided into two. His plate 2 represents a section of the ovary of a cancer mouse. Its Figure 2 closely resembles to Figure 3 of Plate 1 , except that the ovum is divided into 5 and is surrounded by a thick zona pellucida. The growing follicle rejresented in Figure 3 is a little larger in size than that of Figure 2 of the same plate showing an irregular shape and its granulosa layer lacking cell division. Therefore, his description of the divided ova containing much glycogen may be that of the atretic follicles, judging from his figures. 
Hirschler described in his researches with three species of Ascidia that glycogen is positive in the ovum, and it increases in amount as the ovum develops. Ando noticed that glycogen is found, although poor in amount, in the eggs of $\mathrm{dog}$ and cat embryos. Ohashi remarked in his detailed study of the glycogen distribution in various organs of two species each of Anura, Bufo and Rana, in various stages of their lives, that glycogen is not found usually in the ovarian anlage during the larval stage, and even in the adult the glycogen content is different in different seasons. Nakano reported the glycogen distribution in the various organs of the monkey and recorded positive reaction in the ovum.

'The glycogen appearance of the ovum, in my preparations, is different in different animals; in the mouse and the rat it is frequent, in the rabbit rare, and in the guinea-pig it never occurs. Even in the mouse and the rat, the ova of the primitive and growing follicles contain little glycogen (Fig. 6), but those in the mature follicles contain much of it. The ovum contains not only glycogen in granules, globulets or masses, but also glycogen-like substance stained diffusely reddish with carmine. These substances are universally distributed or frequently biased toward the profound part. They may be utilized for the nutrition of the ovum itself.

\section{E. Corpus luteum.}

At the time of the rupture of the mature follicle, the ovum flows out along with some granulosa cells and liquor folliculi, and afterwards there develops a new epithelial organ, i.e., the corpus luteum. As to the development and the retrogression of this body, I have reported formerly the results obtained by the studies of the mouse and the rabbit. Namely, the corpus luteum of the mouse takes the epithelial origin, and that of the rabbit, a double origin. In the retrogression of corpora lutea in both animals, fatty metamorphosis plays an important rôle. As to the glycogen appearance in the corpus luteum and in the interstitial gland, I have never read any report. I shall describe, in the following, the glycogen appearance in the corpus luteum during its various stages, from its formation to retrogression.

The corpus luteum consists of three parts. These are, to enumerate from outer side, the fibrous coat, the lutein layer and the central nucleus.

1. The fibrous coat. This originates from remains in situ of the theca externa of the mature follicle, although a part of it enters the granulosa layer with the spindle-shaped cells of the theca interna to form the connective tissue reticulum among the lutein cells. The 
On the Appearance of Glycogen in the Female Reproductive Glands of Rodents. 469

capsule is, therefore, thinner than the theca externa of the mature follicle, and is clearly marked off from other tissues by the concentric arrangement of the spindle-shaped cells. In the retrogression of the corpus luteum, it disappears early, being pressed by the other tissues converging into the ovarian stroma in the mouse, although it remains until a late stage in the rabbit. This fibrous coat contains no glycogen in any stage.

2. The lutein 'ayer. There are two kinds of lutein cells, i. e., the granulosa lutein cells and the theca lutein cells. In the granulosa lutein cells, the first appearance of glycogen is during their early stages showing hypertrophy. At their enlargement, it becomes larger in amount, and becomes the largest in the growing corpus luteum or in the grown corpus luteum of its early period. 'The glycogen of the young corpora lutea in the same stage is almost the same in quantity, although the corpora lutea show various figure; as corpora haemorrhagica containing blood in their central cavities, corpora lutea containing fluid unstainable with Best's solution, or corpora lutea with central connective tissue nuclei or without them. The fully grown corpus luteum shows usually no glycogen content, but when the corpus luteum is in retrogression, glycogen reappears in the honey-combed cells or in the groups of degenerating lutein cells with pycnotic nuclei. The theca lutein cells of the young corpora lutea of the rabbit show also glycogen content in their cytoplasm.

Thus the glycogen appearing in the lutein cells is restricted to the period of young corpora lutca in hypertrophy or old corpora lutea in retrogression, although lipoids exist abundantly even in the fully grown corpora lutea. These two substances show, therefore, a temporal coexistence in the corpus luteum. As to the significance of lipoids in the corpus luteum, II urao, Jaffé and others noticed lately that they are a stored product, like those found in the cortex of the suprarenal gland. It is clear, however, that the glycogen of the corpus luteum has no such significance by its most remarkable appearance in the early stages of gestation.

The glycogen content of the corpus luteum is remarkable in the rabbit and the guinea-pig, but relatively little in the mouse and the rat. It shows no marked difference between the peripheral and the central part, or between the superficial and the profound part of the corpus luteum. Glycogen does not, however, appear universally in every lutein cell of a corpus luteum, some cells have a little or none even at the stage of its remarkable content (Fig. 1 and 7). 
Glycogen in the corpus luteum shows the appearance of minute globulets existing perhaps coincident with cell granules in a small amount, but shows masses or droplet; biased toward the profound part in its large amount (Fig. 1 and 7). These states may show that glycogen is connected with cell granules, but its comnection is very loose, separated easily by the fixing fluids, especially in its large quantity, just as our Prof. 'T. Asai explained it in the striated muscle fiber's of the mouse.

The blood-vessels among the lutein calls are capillaries only in the. mouse and the rat, although the rabbit and the guinea-pig have besides small arteries and veins. The glycogen appearing in these vessels is largest in amount in the rabbit. Its appearance is during the sameperiods as that of the lutein cells, and it exists not only in their walls, but also in their inner cavities, showing lines of minute granules along. blood vessels.

As described in the introduction, there are two opposite theories as to the condition of glycogen appearance ; namely, the theory of diminution of cell function as insisted on by Gierke, Lubarsch, Rabe, Schütz and others; and the theory of raised metabolic activity as supported by Fichera, Best, Neukirch, Koso and others. In the lutein cells, glycogen appears, however, both in the young corpus luteum to be in increased motabolic activity and in the old corpus luteum to be in the diminution of cell function. Therefore, each of these two theories may be, after all, the inspection of only one side of the shield. The theory that hyperemia is a chief condition of glycogen appearance, which recently was put forth by Koso, can not be adopted to explain all cases of glycogen appearance, as the degenerating lutein cells have no hyperemia.

As to the significance of glycogen appearing in the corpus luteum, it may be different according to cases: 1. In the young corpus luteum in its formation, it may serve as a material for hypertrophy of the lutein cells themselves and a source of energy to fulfil their special function. 2. In the grown corpus luteum in its early stage, it may be consumed in carrying on its function. 3 . In the old corpus luteum in its retrogression, it may come out to give the nutritious substance which becomes unserviceable as its living power declines for other tissues.

3. The central nucleus. The spindle-shaped connective tissue cells of the theca interna and the externa penetrate into the granulosa layer after ovulation, and they reach the central part of the young corpus luteum, where the central nucleus forms. These cells in the central nucleus of the young corpus luteum rarely contain a little glycogen. 
On the Appearance of Glyeogen in the Female Reproductive Glands of Rodente.

arranging concentrically around the central cavity or rumning irregularly in various directions. In the central nucleus of the fully grown corpus luteum, they run usually parallel with one another. But the majority are absorbed, in general, with the degeneration of the lutein colls leaving no trace behind, although some part of them remain to form a corpus fibrosum. They are absent in glycogen in both fully grown corpora lutea and those in retrogression.

\section{F. Atretic follicle.}

A lirge number of follicles fall into atrophy at various stages of their development although a small number of them may fulfil ovulation. This atretic follicle was formerly treated often as a pathological phenomenon. However, no copy appears which asserted it as such since Schottländer, who published a thesis as to the atretic follicle twice and noticed in his conclusion that,, Die Follikelatresie, der Untergang. unge jlatzter Follikel ist bei Mensch und Säugetieren ein physiologischer Vorgang." The predecessors who studied the atretic follicles of the ovaries of the rodent, i. e., Schottlïnder, Rabl, Cohn, Sobotta, Loeb, Benthin, Ascher, Asami, Ioka, Murao and others agree in the principle that by the atrophy of follicles larger than the mediumsized, the theca interna grows contrary to the degeneration of the ovum and the granulosa layer, although the small follicles show the degenerative process only. But they hold many different opinions on their individual phenomena of degeneration or growth.

Atretic follicles appear most frequently in the pregnant period, as may easily be thought from the failure of orulation throughout this period. During the non-pregnant period they occur less frequently and are fewer in number than those of the former period.

The situation of the atretic follicles in the orary is noticeable. Sobotta pointed out that eren the mature follicles, when situated in the profound part of the ovary, may fall into atrophy. Wallart noticed that the atretic follicles are situated usually in the subcortical portion. Atretic follicles in these situations can be found also in my preparations. Loeb described that many follicles fall in atrophy in their premature stage, and the cause of their atrophy is closely connected with their situation, existing at a place suitable for obtaining a blood supply. In other words, follicles at the portion facing the hilum may mature owing to the large blood ressels surrrounding them directly, and another portion may fall into atrophy. My preparations show, however, disagreement with this author, that atretic follicles exist often in such a 
portion as that facing the hilum. Hence the normal ovary may not hold two different portions suitable or unsuitable for blood supply. A - ani exclaimed Heape's description of the atretic follicle, which exists near the large follicle, observing that the former is not always found near the latter. My sections also support A sami's observation.

As we can find, furthermore, the cause of atrophy in the follicle itself, although its situation or pregnancy may play an important rôle as above noticed, I wish to study the changes occurring in every layer of follicles together with the appearance of glycogen in the courst of atrophy, and to solve the open question as to at what layer the first cause of atrophy may exist.

1. The theca folliculi. By the atrophy of the primitive follicles or the small follicles of a few layers of granulosa cells, the theca folliculi remains often in situ surrounding the small cavity formed by the degeneration of the ovum and the membrana granulosa, or eriters into the small cavity to obliterate it thoroughly. These phenomeria can be seen in all rodents and the former may be called' small cystic atrophy'.

a. The theca externa. In the atretic follicles larger than the medium-sized, the spindle-shaped cells of the theca interna increase in number with the growth of the polygonal cells, and surround sereral cells of the latter. Some of them, furthermore, penetrate into the central part through the basement membrame to form the connective tisiue nucleus as that of the corpus luteum. In the early poriod of these changes, some of the spindle-shaped cells of the theca externa are converted into polygonal cells by their hypertrophy, and some of them show also inwandering to surround the polygonal cells with the of the theca interna. 'Therefore, the thicknes of the theca externa of the atretic follicle becomes thinner than that of the normal, growing follicle, contrary to the relation in thickness of the theca interna. In the three animals except the guinea-pig, the outer capsule, i.e., the theca externa of the atretic follicle becomes thin showing sometimes irregular arrangement as Rabl, Cohn and others noticed. Furthermore, advancing the atrophy, the outer capsule lecome torn and disappears under the enormous growth of the theca interna to the interstitial gland. a it comes in contact directly with otber tissues. In the guinea-pig, however, the stroma connective tissue is markedly developed and supplies the decrease of the theca externa. Hence, the interstitial glands are usually localized in a certain territory separated from one another by the outer carsicte of connective tissue. The theca externa of the atretic follicles contain usually no glycogen. 
b. The theca interna. The growth of the theca interna of the atretic follicle is described by almost every author except Schottländer and Asami, and it begins before the total disappearance of the membrana granulosa. The growth changes occurring in the theca interna are the increasing in number of the polygonal cells converting from the spindle-shaped cells, and their enlargement in size surrounded by the spindle-shaped cells and capillaries. Therefore the growth of the polygonal cells is caused by hypertrophy only, as Rabl noticed, lacking the cell divisions although they can be found in the normal Graafian follicles of the rabbit and the guinea-pig. The interstitial gland cells derived from the polygonal cells of the theca interna often show, however, marked cell divisions during the pregnant period. The latter phenomenon agrees with Seitz, Wallart and others' descriptions that the theca interna cells of the human atretic follicles during the pregnant period show both hypertrophy and hyperplasy. As to the growth of the theca interna, Böshagen, Seitz, Cohn and others noticed the centrifugal development contrary to the centripetal of the corpus luteum. Both the corpus luteum and the atretic follicle in my experiment show, however, development both centrifugal and centripetal, i. e., it develops usualiy in the former centripetal at first and then centrifugal, and in the latter almost synchronously.

The spindle-shaped cells among the polygonal penetrate into the iuner cavity containing granulosa cells and the ovum in degeneration through the basement membrane, where they form the central connective tissue nucleus in various shapes. The largest central nucleus can be seen in the orary of the guinea-pig. These central nuclei are composed of connective tissue cells of oval, round or stellated shape in the dense network of the fibers. Capillaries or pigment cells are sometimes noticed in these nuclei.

A little glycogen can often be noticed in the polygonal cells, contrary to the spindle-shaped cells which contain usually no glycogen. Young connective tissue cells of the central nucleus contain, rarely, a little glycogen.

2. The basement membrane. Through the atrophy of the small follicle it shows often the same structure as that of the normal small follicles, constituting the innermost line of the walls of the small cysts. The follicles larger than the medium-sized show two different appearances; i.e., one is almost equal to that of the normal follicle and the other is thickened, falling into hyaline degeneration. These features agrec thoroughly with those of Hörmann's report. At several points of 
this hyaline band connective tissue cells are noticed, which are on the point of wandering through from outside to inside, and some of them are enclosed in the hyaline substance, showing the appearance of Rabl's 'fixe Zellen'. Besides Rabl, Böshagen noticed lutein-like cells and spindle-shaped connective tissue cells in the hyaline membrane, and Cohn also described connective tissue cells in it. The formation of the hyaline membrane can be observed in the rabbit, but rarcly in the guinea-pig, the rat and the mouse. This membrane shows no glycogen content, and the hyaline membrane is stained homogeneously reddish with Best's solution.

3. The membrana granulosa. The granulosa cells disappear chiefly through chromatolysis and the simple atrophy of the nuclei and the fatty degeneration (infiltration) of the cytoplasm. The phenomenon of the chromatolysis is described by Schottlinder. Sobotta, Rabl, Spuler, Wallart, Fellner, Benthin and others since Flemming. It means that the chromatin of the granulosa cells becomes globulets in various sizes stained deeply and then they disappear by dissolving. Simple atrophy means that the nucleus becomes unstainable gradually and dissolves into the liquor folliculi. Besides these degenerative processes of the nuclei, caryorrhexis and prcnosis can also be obicred, but rarely. The cytoplasm of the grauulosa cells disappears as they were or after they are swollen or withered, containing usually substance stained with sudan III. As to the degeneration of the granulosa cells, Loeb noticed, however, that "Die Degeneration der Granulosa findet nicht immer durch Karyorrhexis statt. In mehreren Fällen beobachtete ich eine myxoide Degeneration der Granulosazellen, an Stelle der karyorrhectischen Degenerationsformen. In diesen Fällen fand sich eine grosse Zahl von Pseudoeiern, welche sich aus degenerierenden Granulosazellen bildeten". The granulosa degeneration begins, as a rule, at the part facing the antrum folliculi, and the cells of the corona radiata and the outermost layer of the granulosa remain often relatively long, as $\mathrm{Rabl}$ noticed. In some cases the former degenerates, however, early learing the ovum free in the antrum folliculi.

Contrary to the above descriptions, healthy granulosa cells remain, sometimes, long after the degeneration of the ovum. This phenomenon agrees with Cohn's 'atypische Form der Follikelatresie'. Asami, however, has interpreted such a feature as follows, "Moreover, it seems that, while the ovum after it has once began to degenerate continues in this process until it is completely disintegrated, the granulosa is able to recover in many instances. I am inclined to interpret in this way the 
On the Appearance of Gly'ogen in the Female Reproductive Glands of Rodents. 475

fact in many cases remnants of follicle are found in which the granulosa appears healthy, but in which the egg has been entirely destroyed. It is probable that in such instances a recovery of the granulosa takes place after the egg has been resorbed". I want, however, to interpret it that the degeneration appears first in the ovum and then in the granulosa gradually. Moreover, I am able to maintain the fact that the granulosa cells of the atretic follicles are not only long persistent but also are converted into lutein cells surrounded by the interstitial gland cells in the rabbit ovary, as formerly asserted by Cohn .

In the ovum, or among the granulosa cells in degeneration, appears a special type of cells after the early stages of the follicular atrophy. As to these wandering cells, Schottländer noticed that the cells foumd in the egg belong to the leucocytes and the granulosa cells, and those in the antrum folliculi belong to the wandering cells with special nuclei of lobulated shape from the theca interna. Rabl described "Mit Ausnahme eines einzigen Kernes, welcher sich offenbar in Beginne der Degeneration befindet, sind alle übrigen gross, oval und enthalten ein feinfädiges, chromatisches Gerüst. Es kann sich demnach hier auch nicht um die gewöhnlichen polynuklären Leukozyten handeln. Dagegen zeigen die Kerne ein Übereinstimmung mit der Kernen jener Zellen, welche teils frei in der Flüssigkeit suspendiert, teils der Follikelwandung angelagert sind. Es sind dies dieselben Zellen, welche späterhin den ganzen Follikel ausfüllen und sich wohl durch ihre Form wie ihre Herkunft als eingewanderte Bindegewebeszellen dokumentieren. Ich muss darum auch die im $\mathrm{Ei}$ eingeschlossenen Zellen für solche hatten". Loeb mentioned that in the artretic follicles of the guinea-pig, "Bindegewebe zieht in die Follikelhöhle, desquamierte Bindegewebszellen fungieren als Phagozyten, indem sie einen Teil der degenerierten Granulosazellen in ihren Zelleib aufnehmen". Benthin remarked that the wandering cells in the ovum of the atretic follicle are leucocytes. Evans asserted by vital staining with the azogroup that "True macrophages play an important rôle in follicular atresia and they are electively stained by vital dyes of this class. The later stages of follicular atresia are consequently marked by brilliant deposits of the vital stain due to the vital dye granules in the macrophages concerned here. The macrophages must be considered as utilizing the products of the disintegrating ovum, toward which they are attracted and they invade by an active penetration of the zona pellucida. These are the cells first seen in this act by Pflüger and by Lindgren". Ioka and Murao studied respectively the vital staining with lithium carmine of the rabbit 
ovary and explained that the wandering cells appearing in the atretic follicles are histiocytes which phagocytose the vital dye granules and increase in number as the granulosa degeneration proceeds. Especially, Ioka noticed that these histiocytes appear in the follicle from the surrounding connective tissue through the chemical stimulation caused by the changes of the follicular contents. Asami declared that in the rabbit the ovum and the granulosa layer in degeneration contain often normal, intact granulosa cells, connective tissue cells and, rarely, lymphocytes although small in number. Especially as to the wandering cells of the ovum, he emphasized that "Cells, probably of granulosa origin, can be seen to immigrate into the normal egg at all stages of the sexual cycle and in large, medium and small follicles. These cells usually undergo a rapid disintegration within the substance of the ovum. These cells do not act as phagocytes as long as the egg is healthy, but they may perhaps, do so in case the egg degenerates; only in degenerating eggs of small follicles does one find evidences of phagocytosis".

In my preparations of vital staining with lithium carmine, the cells deposited with red granules in their cytoplasm are found in the orum, especially near the zona pellucida, in the antrum folliculi and among the granulosa cells in degeneration in the early stages of the follicular atrophy. In the follicles of their granulosa in the higher degree of disintegration abundant wandering cells with marked deposit of vital dye granules are seen, especially rich in number in the stage of follicular atrophy with young central connective tissue nucleus, as Iok a noticed. In the more advanced atrophy, they decrease gradually and disappear, contrary to the development of the central connective tissue nucleus. As Iok a noticed, they may be classified into two, the larger and the smaller cells, although many intermediate forms are also noticed. The smaller is in size almost as large as lymphocytes or polynuclear leucocytes, and the larger is 2 or 3 times as large as those of the former, being round or oval in shape. Their nuclei are round, oval, or kidney-shaped with few chromatin, and are excentrically situated in the cytoplasm. The vital dye in their cytoplasm is in granules, globulets or masses. These cells are clearly the histiocytes of Aschoff and Kiyono, and all the cells described by many authors as wandering cells; connective tissue cells, leucocytes, macrophages or granulosa cells may perhaps belong to the histiocytes. Histiocytes in a larger size show a marked phagocytosis. Namely, histiocytes are attracted into the atretic follicles as smaller cells, and they enlarge several sizes by phagocytosing the products of the disintegration of the follicular contents (Ioka). 
On the Appearance of Glycogen in the Female Reproductive Glands of Rodents. 477

In the granulosa cells, in the early stages of their degeneration, fine granules of glycogen are sometimes distributed universally in their cytoplasm, besides the globulets in the swollen cells (Fig. 4) or those with pycnotic nuclei.

Concerning the glycogen of the histiocytes, Gierke and Jubarsch described that epithelioid cells, giant cells and connective tissue cells of the tubercle contain glycogen, and the majority of these cells belong, according to Kiyono, to histiocytes. Oguchi and Majima mentioned that glycogen is seen in the histiocytes in the secretion of the eye. Katase and Mitsuda studied the glycogen distribution in a large variety of tissue of the new born, the monkey, the dog, the cat, the guinea-pig, the rat, the mouse, the domestic fowl, the frog, the carp, the gibcl, the goby, the prawn and the cockle, and noticed that the glycogen content of histiocytes is larger in the lower animals than in the higher as a rule, and histiocytes may concern the carbohydrate metabolism. Okazaki reported in his experimental studies that histiocytes hold the function of glycogen formation. Recently Nakajima asserted by the experiment of injection with grape-sugar into the vitreous body of the rabbit eye, that the listiocytes that wandered into the vitreous body have the function of sugar metabolism, taking sugar in their cell bodies and converting it into glycogen.

As above described, many an author has described that glycogen appears in the histiocytes in a pathological, physiological or experimental condition. However, the histocytes appearing in the atretic follicles usually contain no glycogen, except those that phagocytose the granulosa cells, the ovum in degeneration, or their degenerated masses containing glycogen. Therefore, the histiocytes wandering in the antrum folliculi play perhaps an important rôle in the absorption of the follicular content, not performing sugar metabolism.

4. The liquor folliculi. As soon as the atrophy begins, changes in the composition of the liquor folliculi may perhaps occur, as the liquor folliculi of the mouse and the rat shows a dusty or granular appearance even at the first stage of the atretic follicle, although it is scarcely stained or gives an appearance of strings radially arranged arround the ovum in the normal Graafian follicles. In the rabbit and the guinea-pig it shows, however, a dusty or granular appearance even in the normal Graafian follicles.

Seitz has classified two types of follicular atrophy in the human ovaries, the 'cystische Atresie' and the 'obliterierende Atresie'. The former shows the accumulation of a large quantity of follicular fluid by 
atrophy, and the latter, the obliteration of the antrum folliculi by the eonnective tissue inwandering. These two types of atrophy were adopted by Sobotta, Cohn, Wallart, Benthin, Fellner and many others both in man and mammals. Wolz asserted, however, that "Es giebt nur eine Form der Atresie. Die von Seitz als, cystisch' bezeichnete Atresie ist nur eine Vorstufe der obliterierten". Iy opinion agrees with Wolz's about the type of atrophy, as the liquor folliculi or the cxtravasation of blood into the follicular cavity, which is found sometimes in the rabbit, are absorbed gradually in the atretic follicles of rodents.

The liquor folliculi of the atretic follicle is stained diffuse or granular deeper than that of the normal Graafian follicle, with Best's solution, as Rabl, Wallart, Benthin and others have described concerning other dyes, and it may perhaps contain a glycogen-like substance.

5. The egg. The ovum is usually surrounded by the thick zona pellucida of which, outside or inside, histiocytes may be often seen. The ovum in retrogression often shows an irregular form with germinal vesicle poor in chromaticity and vitellus rich in substance stained with carmine. The ovum in the atretic follicle often shows appearance of dividing into two or more cells with the polar body. As to the dividing phenonomenon of the ova in the ovary, many works have been published, and those of the nineteenth century are collected in Bonnet's thesis entitled 'Giebt es bei Wirbeltieren Parthenogenesis ?' He noticel that "Ich betrachte die besshriebenen Vorgänge (Teilungsvorgängc) nicht als parthenogentische Furchung, sondern entweder als Richtungsspindeln oder aber als dirtkte degenerative Teilung oder gar nur als Frangmentierung". Howerer, spuler noticed in the ovaries of the rodent that the ovum divides into two segment: by a normal method, but afterwards they divide only by their disintegration. Loeb asserted that "In den ovarien von Meerschweinchen können Mitosen rorkommen in sigmentierten Eizellen. Auch zwei gleichzeitige Mitosen können sich in zwei verschiedenen Segmenten finden". In my prejarations of rodents the orum is often divided into two or more segments of an equal size. They are sharply outlined from one another within the zona pellucida. Each contains the round nucleus in a resting stage. Therefore, the orum of the rodent may divide parthenogenetically, although I could not see its segmentation-division. Such a dividing phenomenon of ora can also be seen in those non-fertilized in the Fallopian tube or those remaining in the central carities of the young corpora lutea. When ova are markedly advanced in their retrogression, their nuclei become 
unstainable, and their cytoplasm is divided into many smaller globulets of unequal size.

Glycogen and glycogen-like substances are noticed markedly in these ova, even in the stages of their thorough degeneration within the twisted, thick zona pellucida stained homogeneously reddish with Best's solution. Hence, I can support the opinion of Schütz or Oki that glycogen exists also in the cells clearly dead, not recognizing the descriptions of some authors that cells in degeneration contain no glycogen.

At the time of the egg passage in the Fallopian tube, glycogen appears in the epithelium of its mucous membrane, as described by Koso and Ohashi. Its appearance is especially rich in quantity at the first part (the fimbriae and the ampulla), although it appears in all parts of the tube. Glycogen granules exist not only at the free borders of the epithelial cells, but also at their basal portions. As an interesting picture, the epithelial cells of the second part of the tube in transverse sections contain the granules at free borders in one side, contrary to the basal portions of another. This may be, perhaps, caused by the fixing fluid, which penetrates from one side into the inner cavity and again from here into another side of the tube. Above described features of glycogen appearance in the Fallopian tube are different from those of Koso concerning the rabbit tube. According to his copy, glycogen exists only beneath the nuclei of the epithclial cells, adherent diffusely to the surface of his so-called 'Trägersubstanz'. Furthermore, his denying the appearance of glycogen in the tubes of embryos and sucklings is just opposite to my observation with the same materials.

Now, as the cause of atrophy lies also in the follicle itself, many an author such as Rabl, Böshagen, Seitz, Cohn, Fellner and others noticed that the follicular atrophy may be caused by the growth of the theca interna, which plunders the nutrition of the egg and the granulosa cells. Such appearance as the first change of atrophy occurring in the theca interna can be seen also in my preparations, especially during the pregnant period. But as the atrophy appears also in small follicles showing yet no theca interna differentiation, the cause of atrophy must be searched for in the ovum or the granulosa layer. Besides these, we must also seek for the liquor folliculi, as the changes in its composition may occur in the early period of atrophy, as described before. Schottländer reported that "Die Atresie beginnt in der Mehrzahl der Fälle mit der Zerstörung des Eies; im Laufe der letzten setzen die zum Untergang des Epithels führenden Processe ein; meist vor völliger Vernichtung des Epithels, selten erst später, wird der ent- 
standene Substanzverlust von der 'Theca aus gedeckt". Rabl noticed that, in the smaller follicles, the ova fall into degeneration at first, although in the larger follicle the essential cause of atrophy is often the change in composition of the liquor folliculi. Asami mentioned, "In the case of the small follicle, the sequence of events in atresia is. different from that found in the medium and large follicles, in as much as the first changes appear simultancously in the egg, granulosa and zona pellucida, whereas in the large or medium follicles the first changes. occur in the granulosa and the egg is affected relatively late in the process of atresia".

As above described, the first cause of atrophy may be the abnormal growth of the theca interna, the degeneration of the granulosa cells, the change in composition of the liquor folliculi or the degeneration of egg; besides pregnancy or the deep situation of the follicle. Hence the follicle may fall into atrophy when it possesses even one of these conditions.

\section{G. Interstitial gland.}

All the literature as to the interstitial gland up to date is collected in Stieve's work published lately. In the following I will review more. important work on this gland in man and mammals.

The 'glande interstitielle de l'ovaire' was first described by Limon in the mouse, rat, rabbit, guinea-pig, bat, mole and hedgehog. He noticed that it is an endocrine organ derived from the theca interna of the atretic follicle. Cohn noticed also the interstitial gland to be of the same function in the rabbit ovary. Fraenkel and Schaeffer described in man and a large variety of mammals that the interstitial gland may not perform a definite function, as man and the monkey possess no interstitial glands, their existence and quantity being indefinite in various animals, and being derived from the organs of no essential function, i. e., the atretic follicles. Benthin noticed in mammalian ovaries that "Selbst in Eierstöcken ganz junger Tiere kann sich ein interstitielles Gewebe finden, jedoch nur dann, wenn es zur Ausbildung grösserer Follikel bereits gekommen ist. Stets ist dieBildung des interstitiellen Gewebes auf die Theca interua degenerierter Follikel zurückzufühlen". Bascom studied the intristitial gland of gonads of cattle, and said that "Interstitial cells were not found at any stage in the medulla of the ovary. They were found in the cortex only after $82 \mathrm{~cm}$. (embryos) occurring solely in the theca interna of follicles, best developed in those which wre atretic." 
As to the interstitial gland in man, Wallart noted the change of the theca interna cells into the epithelioid cells during gestation or hydatid mole. Seitz noticed also in the ovaries of the physiological and pathological pregnancy, that the theca lutein cells formed by the enlarged theca interna cells of the atretic fullicles are homologous to the interstitial gland cells of mammals from morphological standpoints. Wallart related again that the interstitial gland in man is seen only during a period in which ovaries contain the growing follicles; its maximum development is reached during a stage from the new born to puberty, and afterwards it decreases, although found in larger amount than the normal at stages of monthlies and physiological and pathological pregnancy. Winiwarter mentioned that the connective tissue cells form the interstitial gland cells by increasing their cytoplasm and their nuclei being rounded in the human ovaries during embryonal stage. Fellner reported that the 'Körnerzellen' of the theca interna grow and produce internal secretion in the pregnant human ovaries. Wolz also noticed the interstitial gland with the same significance derived from the theca interua. Aschner explained that the interstitial glands exist directly after birth in the human ovaries as Wallart described, but contrary to him their highest developmont is reached within a year after birth, and afterward they decrease to a small amount at the pubertal stage. However they increase at the late stage of pregnancy as in infants, also in animals. Lahm noticed that "Im Ovarium muss man zwei Arten von interstitielle Zellen unterscheiden. Erstens: die echten intcrstitiellen Zellen, welche Pflüger wohl als Erster, spüter $\mathrm{His}$ u. a. als, kleine Zellen, über deren Bedeutung man sich nicht klar sei ' oder als , Kornzellen ' usw. im Orarium der Katze beschriechen haben. Zweitens: die Theca interna-Zellen der atretischen Follikel". Moreover he remarked as to the genesis of the interstitial gland that "Es ist die Pubertätsdrüse beim Weibe bindegewebiger Herkunft. Auch sie kommt zu allen Zeiten der postembryonalen Entwicklung, jedenfalls bis zur Klimax vor und bildet sich daun aus, wenn ovula nach einer gewissen Entwicklungsstufe des Follikels im Follikel (Ausbleiben der Ovulation) zugrunde geben ".

The interstitial glands of rodents examined by me are scattered in the cortex, converging into one another, and they are derived from the different follicles in atrophy. In the ovaries of the guinea-pig, however, they are separately localized in a certuin territory, owing to the large amount of ovarian stroma. Such a picture can be sometimes scen in a part of the rabbit ovary. The interstitial gland cells are grouped 
irregularly, containing blood vessels or comnective tissue cells among them. All of these cells are originated from the polygowal cells of the theca interna of the atretic follicles, as I never saw the intcrstitial gland cells in the ovaries of embryos and sucklings, nor Seitz's so-called stroma lutein cells in the adult ovaries.

I am able to distinguish the following three stages of the interstitial gland cells; the young interstitial gland cells, the grown interstitial gland cells and the degenerating interstitial gland cells.

1. The young interstitial gland cells closely resemble the polygonal cells of the theca interna of the atretic follicle, and are found in the guinea-pig, rat and mouse in non-pregnant period. They contain round nuclei, stained deeply with hematoxylin, and cytoplasm of granular or slightly honey-combed appearance containing substance stained sudan III. As to these cells, Jue b described as followings: "Die Theca interna der atrcsierenden Follikel entspricht dem Gewebe, das in den Ovarien ciniger Tiere als interstitielle Drüse bezeichnet wird. Beim Meerschweinchen haben diese Zellen nicht den Charakter von Drüsenzellen. Fernerhin ist es auch deshalb unwahrscheinlich, dass dic sogenannte interstitielle Drüse beim Mcerschweinchen von grosser, den sexuellen Zyklus regulierender Bedeutung ist, weil sie in den der Orulation folgenden sechs Tagen besonders im Ovarium praeponiert, und weil sie ferner in relative alten 'Tieren stärker entwiekelt ist als in Jungen ; in das Alter der sexuellen Reife eingetretenen Ticren."

2. The grown interstitial gland cells are large and polygonal, but a little smaller than the lutein cells; their round nuclei are less deeply stained with hematoxylin than those of the young types, and their cytoplasm are largely honey-combed and stained deeply with eosin. They are always found richly in the rabbit ovary, besides the ovaries of the mouse and rat during the pregnant period, although they are absent in the guinea-pig. Therefore my observation agrees with Sobotta's description that the enlarged theca interna cells exist only in the rabbit, the other species of rodents rarely having them. Aschner noticed that some interstitial gland cells of the rabbit contain marked pigment, those of the guinea-pig being localized in the round territories or lobules contrary to their general distribution in the rabbit, those of the mouse and rat are smaller in amount, their ovaries containing rich stroma connective tissue. His observation agrees with my own, except in the amount of the stroma connective tissue in the latter species.

3. The degenerating interstitial gland cells are the fully grown ones in retrogression, which never revert to the former connective tissue cells. 
On the Appearance of Glycogen in the Female Reproductive Glands of Rodents.

Their cytoplasm are usually slightly stained with eosin, often containing yellow pigment, and their nuclei show various figures of degeneration. Concering the retrogression of the interstitial gland cells, Cohn, Böshagen, Benthin and others remarked that these cells can revert to be connective tissue cells. Seitz explained that the majority of the theca lutein celis disappear by hyaline degeneration, besides by the usual degenerative processes, and a part of them revert to the former spindle-shaped cells. Wolz, Ioka and others noticed that all of the cells disappear by degeneration. The grown interstitial gland cells in my preparations disappear through various forms of degeneration, although certain young interstitial gland cells may revert to the spindle-shaped cells.

The glycogen appearance is different in different animals. In the rabbit, it appears markedly during the early period of gestation, although it is scarcely found during other periods. When it appears markedly, it is in globulets or masses in the cytoplasm of the interstitial gland cells in their various stages ( $\mathrm{Fig} .2$ and 8). Furthermore, it appears in the inner cavities of the blood-vessels among the interstitial gland cells in larger quantity than in the latter. The young interstitial gland cells of the guinea-pig are often rich in glycogen even in the non-pregnant stage. In the mouse and rat, it appears rarely and that scarcely.

The significauce of the glycogen appearance in the interstitial gland cells may be the same as that in the lutein cells; namely, in the young interstitial gland cells it may be utilized for their nutrition and their function, in the grown cells it may be solely for function, and in the degenerating types for the benefit of other tissues. The interstitial gland cells also contain substance stained with sudan III in their cytoplasm, as the lutein cells. Hence fatty substance and glycogen show a temporary coexistence. Only because of this feature, I can not deny the antagonistic existence of fat and glycogen asserted by many authors.

\section{Conclusion.}

1. Stage of the glycogen appearance in the ovary.

For studying glycogen accurately timed material is most important; namely, glycogen of the ovaries must be studied in the materials obtained at known stages of sexual cycle, rather than in a large number of them. The adult ovaries of the rodent usually contain no glycogen except in the ova, but in the tissues to be described below, it appears temporarily at certain stages as follows: 1 . early stage of gestation, 2. soon after parturition 3. stage of corpus luteum formation during the non-pregnant stage. 
The ovary of the embryonal stage often contains a little giycogen in the germinal epithelium, Pflüger's egg tubes and nests of cells and walls of blood vessels.

2. Locality of the glycogen appearance in the ovary.

Glycogen appears abundantly in the ovum, the corpus luteum and the interstitial gland besides in the smooth muscle fibers. Glycogen of the ova increases in amount gradually from the primordial follicles up to the mature, being especially rich in the divided and the degenerating ova (Goldmann, Ohashi). The lutein cells of the corpus luteum are chiefly derived from. the gramulosa cells of the Graafian follicle in which they usually contain no glycogen in the healthy condition. Glycogen appears richly in the lutein cells at the early stage of their hypertrophy and exists up to the early stage of the grown corpus luteum. During the most of the period of grown it disappears totally, and then it reapjears in the degenerating lutein cells. The interstitial gland cells are originated from the polygonal cells of the theca interna of the atretic follicle in which they contain usually a little glycogen. Glycogen appears in the interstitial gland at above-described stages. The blood vessels of the corpus luteum and interstitial gland contain glycogen in their inner cavities chicfly during the early stage of gestation in the rabbit. The glycogen content of the smooth muscle fibers in the walls of the blood vessels and at the hilum is quito different in different animals. The glycogen of the former is often noticed in the guinea-pig and mouse, although found in the rabbit only during the early stage of gestation and in the rat directly after parturition. The glycogen of the latter is often found and rich in quantity in the guinea-pig, but in the rabbit only during the early stage of pregnancy, and in both the mouse and rat only directly after parturition.

3. State of glycogen in the ovary.

The glycogen of the above-described cells appears in their cytoplasm, never in their nuclei. Glycogen in the cytoplasm shows the appearance of fime granules which in small amount exist perhaps in connection with the ccll-granules but when it is in a large amount it takes the form of droplets or masses which are biased toward the profound part of the ovary. Glycogen may yet be connected with cell granules, but the connection is very loose and can be easily separated by the fixing fluid, especially when it is in large amount (Asai).

4. Condition of the glycogen appearance in the ovary.

The condition of the glycogen appearance has been investigated with inconclusive results as described in the introduction. I cau not find a 
On the Appearance of Glycogen in the Female Reproductive Glands of Rodents. 48j

definite condition to explain the physiological appearance of glycogen in the ovaries. Especially its appearance can never be adequately explained by any condition mentioned by previous authors. Hence, I am inclined to think that glycogen appears likely under various conditions according to the different significances, and there is probably no single condition to explain the whole of the glycogen appearance.

5. Significance of glycogen in the ovary.

The significance of glycogen may be difforent in different tissues and in different stages. 1. Glycogen in the ovum may serve as the nutrition for the ovum itself. 2. Glycogen of the smooth muscle fibers may be utilized for their function. 3. Glycogen of the young lutein cells and interstitial gland cells may be utilized for their development and function. 4. Glycogen of the grown lutein cells and interstitial gland cells may be solely for their function. 5. Glycogen in the ovum, in the lutein cells and in the interstitial gland cells in their retrogression may be liberated and taken up by other organs, as it becomes useless for the degenerated cells.

In conclusion, I wish to express my hearty thanks to Professor "T. Asai for his kind guidance and helpful advice.

\section{Bibliography.}

1. Ando, K., Glycogen distribution in the mammalian and human placenta and in the embryos. Kinki Fujinka Gakkai Zasshi. Vol. 5. 1917.

2. Arnold, J., Zur Morphologie des Muskelglykogens und zur Struktur der quergestreiften Muskeliaser. Arch. f. mikr. Anat. u. Entw. Bd. 73. 1909.

3. - Zur Morphologie des Glykogens des Herzmuskels nebst Bemerkungen über dessen Struktur. Arch. f. mikr. Anat. u. Entw. Bd. 73. 1909.

4. Aschheim, S., Über den Glykogengehalt der Uterusschleimhaut. Zentralbl. f. Gyn. Jg. 35. S. 1065. 1911.

5. Aschner, B., Über Morphologie und Funktion des Ovariums unter normalen und pathologischen Verhältnissen. Arch. f. Gyn. Bd. 102. 1914.

6. Barfurth, D., Vergleiehende histochemische Untersuchungen über das Glykogen. Arch. f. mikr. Anat. Bd. 25. 1885.

7. Bascom, K.F., The interstitial cells of cattle with especial reference to their embryonic development and significance. Amer. Journ. of Anat. Vol. 31. 1923. 
8. Benthin, W., Über Follikelatresie in kindlichen Ovarien. Arch. f. Gryn. Bd. 91. 1910.

9. —, Über Follikelatresie in Säugetierovarien. Arch. f. Gyn. Bd. 94. 1911.

10. Best, F., Über Glycogen, insbesondere seine Bedeutung, bei Entzündung und Eiterung. Ziegler's Beitr. Bd. 33. 1 s03.

11. —_ Die Bedeutung pathologischen Glycogengehaltes. Zentralbl. f. ally. Path. u. path. Anat. Bd. 18. 1907,

12. Bonnet, R., Giebt es bei Wirbeltieren Parthenogenesis? Ergebn. d. Anat. u. Entw. Bd. 9. 1899.

13. Cohn, F., Zur Histologie und Histogenese des Corpus luteum und des interstitiellen Ovarialgewebes. Arch. f. mikr. Anat. u. Entw. Bd. 62. 1903.

14. Driesen, L.F., Glykogenproduktion eine physiologische Funktion der Uterusdrüsen. Zentralbl. f. Gyn. Jg. 35. S. 1308. 1911.

15. Erans, H.M., On the beharior of the ovary and especially of the atretic follicle towards vital stains of the azo group. Anat. Rec. Vol. 10. Abstr. 66. 1916.

16. Fellner, O.O., Zur Histologie des Ovariums in der Schwangerschaft. Arch. f. mikr. Anat. u. Entwickl. Bd. 73. 1909.

17. Fichera, G., Über die Verteilung des Glykogens in verschiedenen Arten experimenteller Glykosurie. Ziegler's Beitr. Bd. 36. 1904.

18. Fraenkel, L., Vergleichend histologische Untersuchungen über das Vorkommen drüssiger Formationen im interstitiellen Eierstocksgewebe (glande interstitielle de l'ovaire). Arch. f. Gyn. Bd. 95. 1905.

19. Gierke, E.. Das Glykogen in der Morphologie des Stoffwecksels. Ziegler's Beitr. 37. 1905.

20. - - Physiologische und pathologische Glykogenablagerung. LubarschOstertag.'s Ergebn. Jg. 11. Abth. 2. 1907.

21. Goldmann, E.E., Die äussere und innere Sekretion des gesunden und kranken Organismus im Lichte der "Vitalen Färbung." Teil II. Bruns" Beitr. Pd. 78. 1912.

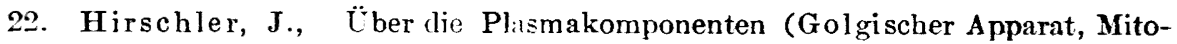
chondrien u.a.) der weiblichen Geschlechtszellen (zytologische Untersuchungen am Iscidien Ovarium). Arch. f. mikr. Anat. u. Entw. Bd. 89. 191 .

23. Ioka, T., Vital staining of the female reproductive organs. Kyoto Igakkai Zasshi Vol. 14. 1917.

24. I wata, S., On the cyclic changes of the Fallopian tube. Hokkaido Igakkai Zasshi Vol. 1. 1923.

2.). Jaffé, R., Bau und Funktion des Corpus luteum. Zentralbl. f. Gyn. Jg. 48. S. 1122.1924.

21. Kalbermatten, J., Beobachtungen über Glykogen in der glatten Muskulatur. Virchow's Arch. Bd. 214. 1913.

¿-. Katase, T. and Mitsuda., I., Comparative histological studies of glycogen distribution in various animals, etc. Osaka Igakkai Zasshi Vol. 17. 1918. 
On the Appcarance of Glycogen in the Female Reproductive Glands of Rodents. $48 T$

28. Kato, K., Beiträge zur Frage des mikroskopischen Nachweises des Glykogens. Pfl üger's Arch. Bd. 127. 1909.

29. Kiyono, K., Studies on vital staining, etc. Tokyo 1920 .

30. Krestadt, W., 'Über Glykogenablugerung. Labarsch-Ostertag's Ergebn. Jg. 15. Abth. II. 1911.

31. Koso, T., On the glycogen appearance in the mucous membrane of the Fallopian tube. Kyoto Igakkai Zasshi Vol. 15. 1918.

32. Lahm, W., Zur Entwicklung der interstitiellen Drüsen im Hoden und Ovarium. Monatschr. f. Geb. u. Gyn. Bd. 58. 1922.

33. Langhans, Th., Über Glykogen in pathologischen Neubildungen und den menschlichen Eihäuten. Virchow's Arch. Bd. 120. 1890.

34. Loeb, L., Über hypertrophische Vorgänge bei der Follikelatresie nebst Bemerkungen über die Oozyten in den Marksträngen und über Theilungserscheinungen am Ei im Ovarium des Meerschweinchens. Arch. f. mitr. Anat. u. Entw. Bd. 65. 1905.

35. - Der normale und pathologische Zyklus im Ovarium des Säugetiers. Virchow's Arch. Bd. 206. 1911.

36. Lubarsch, O., Über die Bedeutung der pathologische Glykogenablagerung. Virchow's Arch. Bd. 183. 1906.

37. Markowitz, J., Glyconeogenesis. Amer. Journ. of Physiol. Vol. 74. 192.5.

38. Mukai, K., On the glycogen appearance in the Fallopian tube. Tokyo. Igi Shinshi. Vol. 1951. 1915.

39. Murao, S., Lipoid-problem in the ovary and uterus, Kyoto Inakkai Zasshi. Vol. 19. 1922.

40. Nakano, O., Glycogen distribution in the various organs of the monkey. Hokuetsu Igakkai Zasshi. Vol. 40. 1925.

41. Nakashima, Ch., Experimentelle studien über die Wirkung der Injektion ron Proteinkörpern und Traubenzucker in den Glaskörper. v. Graefes Arch. f. Ophth. Bd. 116. 1926.

42. Teubert, W., Über Glykogenbefunde in der Hypophyse und im Zentralnervensystem. Ziegler's Beitr. Bd. 45. 1909.

43. Neukirch, P., Über morphologische Untersuchungen der Muslielglykogens und eine neue Art seiner Fixation. Virchow's Arch. Bd. 200. 1910.

44. Niederehe. W., Beitrag zur Glykogenhypothese. Arch. f. Gyn. Bd. 119. 1923.

45. Oguchi, Ch. and Majima, K., Weitere Untersuchungen über das Augensekret. v. Graefes Arch. f. Ophth. Bd. 111. 1923.

46. Ohashi, Y., Histophysiological stndies of the placenta. Part 1. Tokyo Inakkai Zasshi. Vol. 34. 1920.

47. - Histophysiological studies of the placenta. Part II. Toliyo Imakkai Zasshi. Vol, 36. 1922. 
48. Ohashi, Y., Histochemical studies of glycogen. Hokuetsu Igakkai Zasshi. Vol. 37. 1922.

49. - Glycogen distribution in the Anura. Hokuetsu Igakkai Zasshi Vol. 38. 1923.

50. Okazaki, M., On the fate of the starch injected into the blood ressel. Nippon Byorigakkai Zasshi. Vol. 7. 1918.

51. Oki, T., Histochemical studies of the cancer of the uterus. Aichi Irakkai Zasshi. Vol. 30. 1923.

52. Ono, S. and Kik'awa, N., On the glycogen of the endometrium. Nippon Fujinka Gakkai Zasshi. Vol. 15. 1920.

53. Rabe, F., Exprrimentolle untersuchungen über den Gehalt des knorpels an Glykogen und Fett. Ziegler's Beitr. Bd. 48. 1910.

54. Rabl, H., Beitrag zur Histologie des Eierstocks des Menschen und der Säugetiere nebst Bemerkungen über die Bildung von Hyalin und Pigment. Anat. Hefte Bd. 11. 1898.

55. Richard, G., Über die Einfluss der Funktion auf den Glykogengehalt der glatten Muskulatur. Ziegler's Beitr. Bd. 61. 1916.

56. Schaeffer, A., Vergleichend histologische Untersuchungen übər die interstitielle Eicrstocksdrüse. Arch. f. Gyn. Bd. 94. 1911.

57. Schottländer, J., Beitrag zur Kentniss der Follikelatrosie nebst einigen Bemerkungen über die unveräıderten Follikel in den Eierstöcken der Säugeticre. Arch. f. mikr. Anat. Bd. 37. 1891.

58. — - Über den Graafschen Follikel, seine Entsteh:ung beim Menschen und seine Sthicksale bei Menchen und Säugetieren. Arch. f. miskr. Anat. Bd. 41. 1893.

50. Schütz, H., Histolıgische Untarsuchungen übor pat'lolorische Glykogenablagerung. Ziegler's Beitr. Bd. 57. 1914.

60. Sobotta, J., Follikelatrophie und Follikelatresie im Eierstock der Sängetiere. Physical.- Med. Ges: Wurzburg. cit. n. Schwalbe's Jahresberichte. 1906.

61. Spuler, A., Über die Theilungserscheinungen der Eizellen in dege:aerierenden Follikeln des Säugerovariums. Anat. Helte Bd. 16. 1901.

62. Stieve, H., Entwicklung, Bau und Bedeutung der Keindrüsenzwischenzellen. Ergebn. d. Anat. u. Entw. Bd. 23. 1923.

63. Sundberg, C., Das Glykogan in menschlichen Embryonen von 15, 27 und $40 \mathrm{~mm}$. Zeitschr. f. Anat. u. Entw. Bd. 73. 1924.

64. Togari, Ch., On the origin of the corpus luteum of the mouse. Aichi Journ. of Exper. Med. Vol. 1. 1923.

65. - On the retrogression of the corpus lutcum of the mouse. Aichi Journ. of Exper. Med. Vol. 1. 1924.

66. - - On the corpus luteum of the rabbit. Folia Anat. Jap. Bd. 4. 1926.

67. Wallart, J., Über die Ovarialveränderungen bei Blasenmole und normaler Schwangerschaft. Zeitschr. f. Geb. u. Gyn. Bd. 53. 1904.

68. - - Untersuchungen über die interstitielle Gewebe der menschlichen Ovarien. Arch. f. Gyn. Bd. 81. 1907. 
On the Appearance of Glycogen in the Female Reproductive Glands of Rodents. 489

69. Winiwarter, H., Das interstitielle Gewebe der menschlichen Ovarien. Anat. Anz. Pd. 33. 1908.

70. Wolz, E., Untersuchungen zur Morphologie der interstitiellen Eierstocksdrüse des Merichen. Arch. f. Gyn. Bd. 97. 1912.

\section{Explanation of figures (Plate XLIV-XLV).}

All of the microphotographs are taken with Zeiss, Obj, $4 \mathrm{~mm}$. Ok. K. 12., except the figure 6. in which Zeiss, Obj. $16 \mathrm{~mm}$. Ok K. 8. were used.

Fig. 1. Glycogen of a nearly grown corpus luteum graviditatis at 6 days after copulation in the rabbit.

Fig. 2. Glycogen of the grown interstitial gland in the rabbit at the same day as. above.

Fig. 3. Glycogen of the corpus luteum ovulationis in its formation at 45 days after parturition in the mouse.

Fig. 4. Glycogen of the degenerating granulosa cells which are facing the antrum folliculi of an atretic follicle at 8 days after copulation in the mouse.

Fig. 5. Glycogen of the smooth muscle fibers at the hilum in longitudinal and transverse sections directly after parturition in the rat.

Fig. 6. Glycogen and glycogen-like substance of the ovum and glycogen-like substance in the liquor folliculi of the growing follicle in the rat at the same stage.

Fig. 7. Glycogen of the young corpus luteum ovulationis in the guinea-pig.

Fig. 8. Glycogen of the interstitial gland in the guinea-pig at the same stage. 
FOLIA ANATOMICA JAPONICA, BD. V.

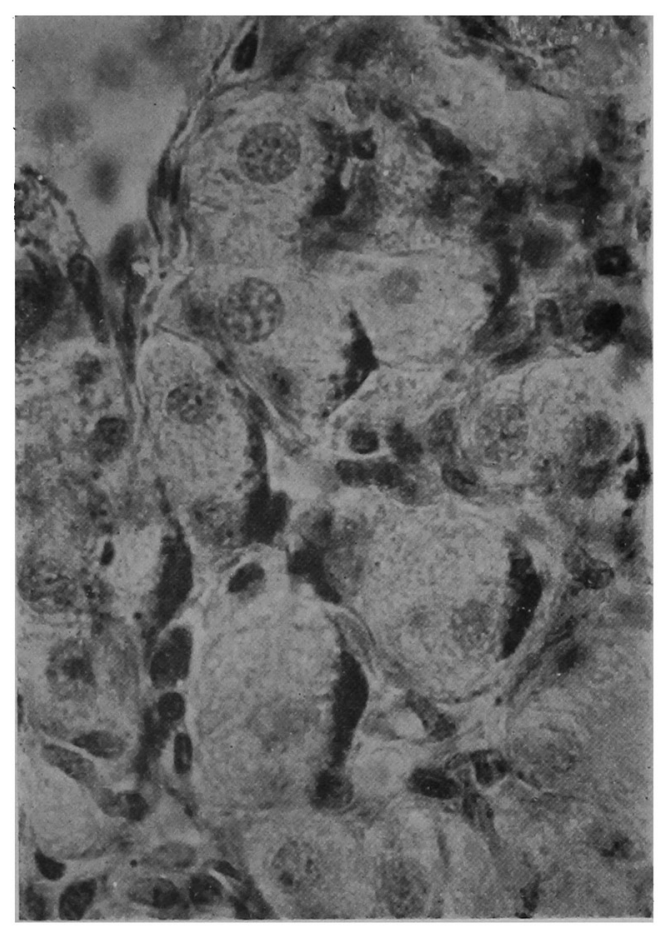

Fig. 1.

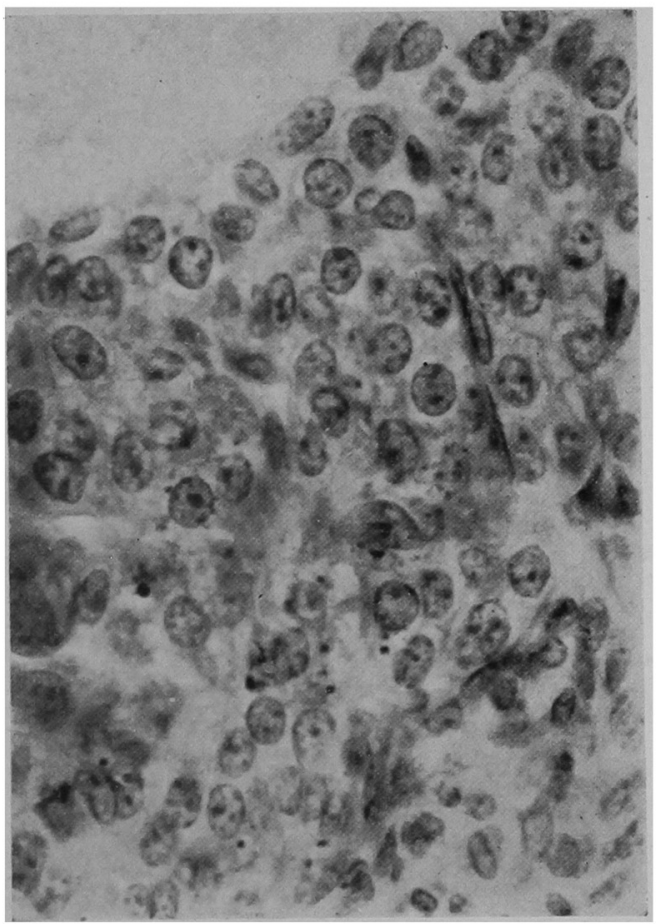

Fig. 3.
TAF. XLIV.

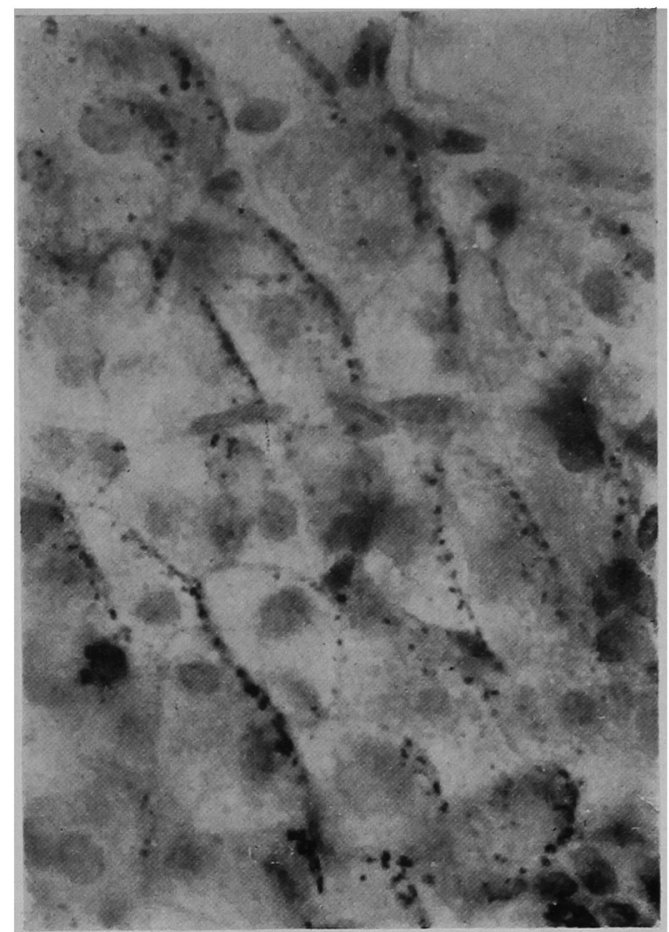

Fig. 2.

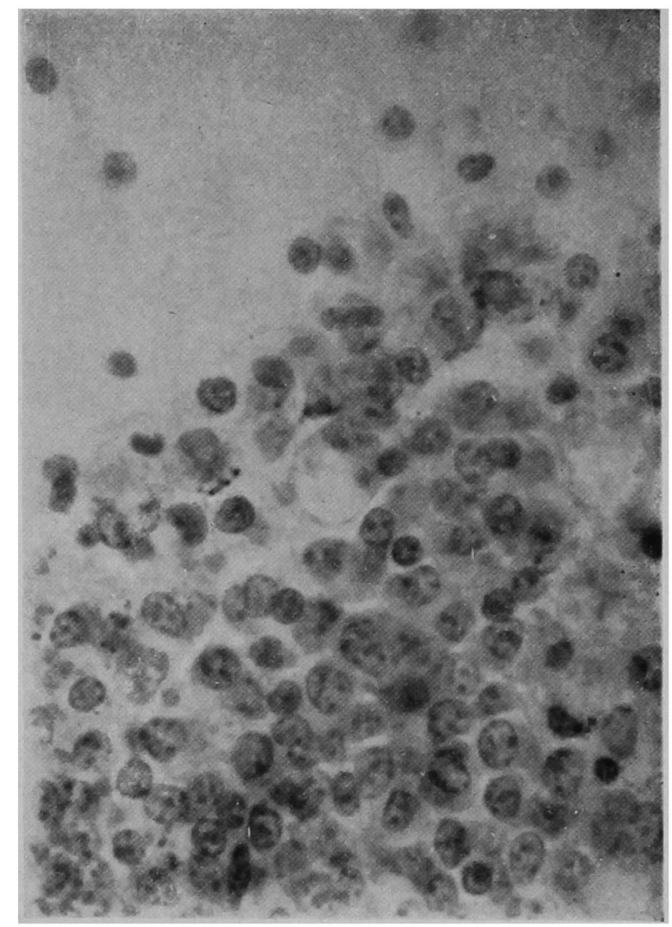

Fig. 4.

Ch. Togari. 


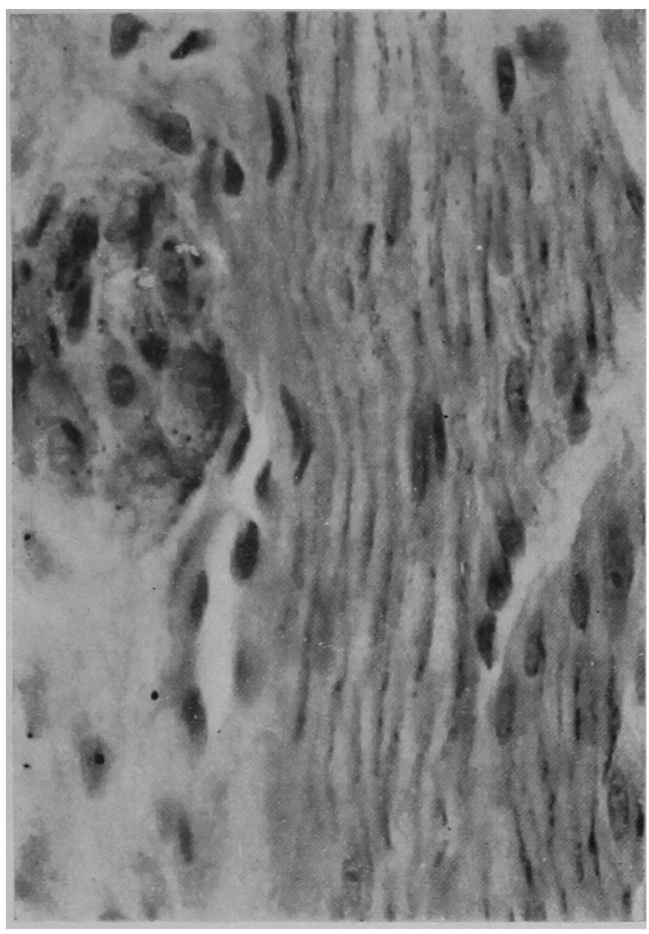

Fig. 5.

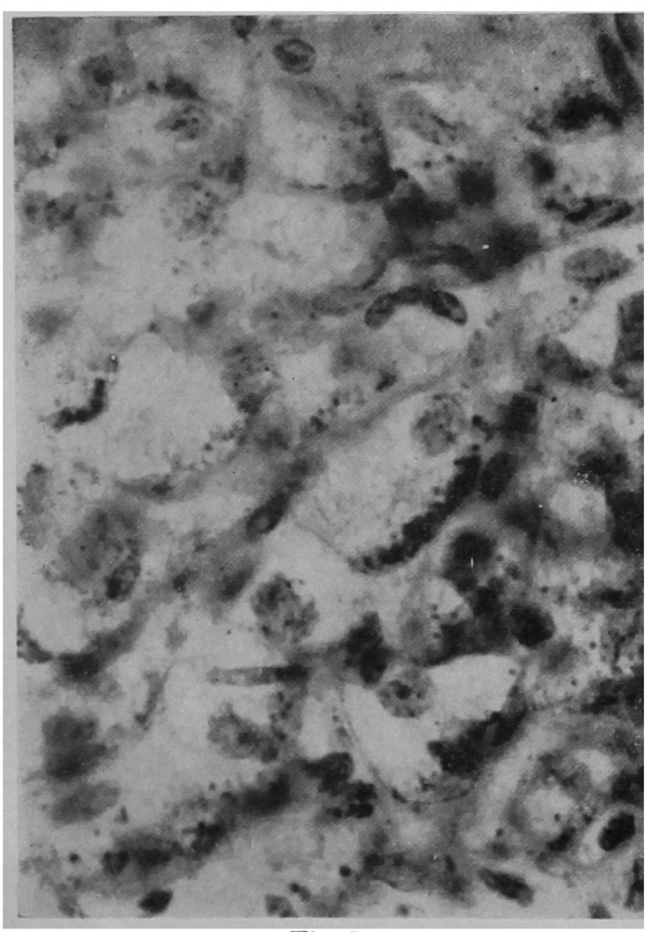

Fier. 7 .

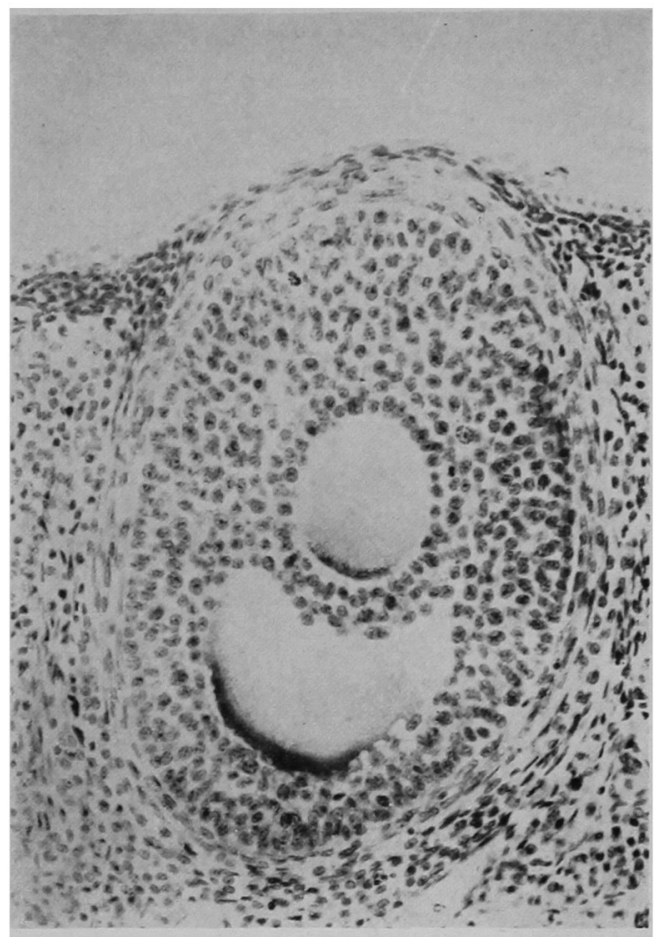

Fig. 6.

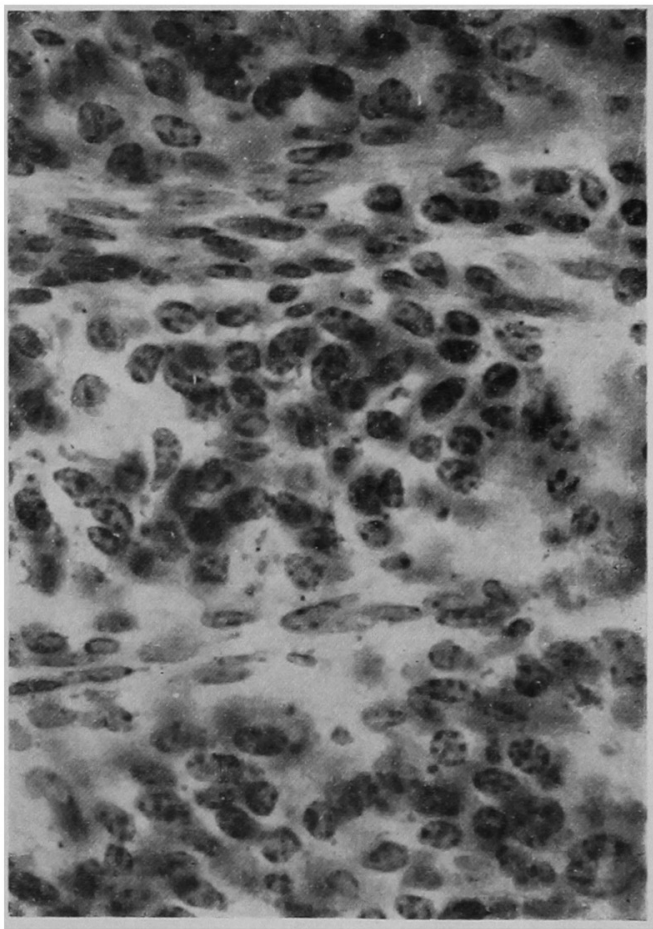

Fies.

C'h. Togari. 